\title{
Gravitational reactivation of a pre-existing post- Caledonian fault system: the deep-seated gravitational slope deformation at Middagstinden, western Norway
}

\author{
Markus Schleier ${ }^{1}$, Reginald L. Hermanns ${ }^{2,3}$, Ingvar Krieger ${ }^{1}$, Thierry Oppikofer ${ }^{2}$, \\ Trond Eiken ${ }^{4}$, Jan Steinar Rønning ${ }^{2}$ \& Joachim Rohn' \\ ${ }^{1}$ University of Erlangen-Nürnberg (FAU), GeoZentrum Nordbayern, Erlangen, Germany. \\ ${ }^{2}$ Geological Survey of Norway (NGU), Trondheim, Norway. \\ ${ }^{3}$ Norwegian University for Science and Technology (NTNU), Department of Geology and Mineral Resources Engineering, Trondheim, Norway. \\ ${ }^{4}$ University of Oslo (UiO), Department of Geosciences, Oslo, Norway.
}

E-mail corresponding author (Markus Schleier): markus.schleier@fau.de

The origin of linear features in mountain terrain that form distinct vertical steps is generally not obvious and has been discussed to be related to either tectonic faulting or gravitational slope deformation. A strong geomorphological lineament running oblique to the slope and forming a convex step in the topography is located on the mountain Middagstinden just west of the valley Innfjorddalen, western Norway. In previous studies this lineament has been interpreted to be the surface expression of a Holocene reverse fault previously called the Berill Fault, indicating the first evidence for neotectonic faulting in southern Norway. Now, detailed structural field mapping has revealed the existence of a set of normal fault planes striking subparallel to this lineament and to the main extensional faults associated with the Caledonian collapse. Electric resistivity tomography (ERT) profiles of the valley floor and excavated parallel trenches confirm the regional extent of the fault, but the sediments observed in the trenches do not indicate any Holocene activity. Furthermore, the lineament is a limiting structure of a large rock-slope instability. Kinematic feasibility tests based on structural field measurements indicate wedge failure along the intersection of the fault and the local foliation. However, this intersection line is not exposed on the slope surface. Hence, simple wedge or translational sliding along the slope is not feasible, except in its uppermost part. Both the displacements observed by differential global navigation satellite system (dGNSS) surveys and the geomorphological characteristics, for instance, counterscarps, superficial mass movements, coherent slide blocks and slope bulging, indicate complex deformation mechanisms. The deformation evidently changed along the slope in type and degree including planar sliding in the uppermost part, potentially large wedge sliding in the middle part, and incremental internal deformation in a direction out of the slope in the lower part. The complex kinematics and geomorphological characteristics account for the definition of a deep-seated gravitational slope deformation (DSGSD). Furthermore, the findings reveal that the geomorphological lineament is of gravitational origin and not neotectonic. It has formed by a reactivation of the pre-existing, Caledonian, normal fault system due to the DSGSD, and is hence an example of pseudotectonics ('apparent reverse fault').

Keywords: Berill Fault, pseudotectonics, DSGSD (Deep-seated Gravitational Slope Deformation), geomorphology, structural geology

Received 16. December 2015 / Accepted 16. May 2016 / Published online 21. July 2016

\section{Introduction}

Large rock-slope instabilities such as deep-seated gravitational slope deformations (DSGSD) show typical geomorphological features and often complex kinematics and deformation processes (e.g., Dramis \& Sorriso-Valvo, 1994; Agliardi et al., 2001). These phenomena are quite common in mountain ranges throughout the world, especially in areas with high topographic relief composed of anisotropic fractured and tectonised rocks. Mass movements, in general, are influenced and controlled by tectonics and geology (Hutchinson, 1988) and it has been shown that large rock-slope instabilities are generally strongly controlled by pre-existing geological

Schleier, M., Hermanns, R.L., Krieger, I., Oppikofer, T., Eiken, T., Rønning, J.S. \& Rohn, J. 2016: Gravitational reactivation of a pre-existing postCaledonian fault system: the deep-seated gravitational slope deformation at Middagstinden, western Norway. Norwegian Journal of Geology 96 , 201-222. http://dx.doi.org/10.17850/njg96-3-03. 
structures, such as, bedding, metamorphic foliation, joint sets of various origin, or tectonic faults (e.g., the abovementioned references on DSGSD; Braathen et al., 2004; Saintot et al., 2011). Especially major tectonic features could lead to a spatial cluster of rock-slope failures (e.g., Hermanns \& Strecker, 1999; Ambrosi \& Crosta, 2006) because of tectonic activity and damage (Brideau et al., 2009) that could have caused distinct weakness zones or even have triggered the failure. Neotectonic activity and seismicity and active tectonics have been identified and discussed as triggers for rock-slope deformations and failures (e.g., Hermanns et al., 2001; Osmundsen et al., 2009; Penna et al., 2011). Besides tectonic activity, other processes are suggested to favour or trigger large rockslope failures in (previously) glaciated high mountain areas. These are especially glacial debuttressing (e.g., Evans \& Clague, 1994; Cossart et al., 2008), decay of permafrost (e.g., Fischer et al., 2006; Blikra \& Christiansen, 2014) and subsequent progressive failure (e.g., Eberhardt et al., 2004, Hermanns et al. 2012a).

Detailed integrative site studies (e.g., Welkner et al., 2010; Böhme et al., 2013; Booth et al., 2014) increase our knowledge of the complex processes of rock-slope failures and enable us to link the mechanism and amount of deformation to the geomorphological surface expression. Those studies combine classic geomorphological and geomechanical field mapping with various deformation monitoring techniques (e.g., Oppikofer et al., 2009; Booth et al., 2013; Wolter et al., 2014). Geophysical investigations provide links to the subsurface (e.g., Ganerød et al., 2008; Willenberg et al., 2008) and numerical modelling allows us to study the pre- and post-failure mechanisms (e.g., Stead et al., 2006; Gischig et al., 2011). Surface-exposure dating with terrestrial cosmogenic nuclides helps to show the temporal distribution and long-term slide velocities of rock-slope failures (e.g., Hippolyte et al., 2009; Hermanns et al., 2012b, 2013). Nevertheless, geomorphological analysis of the slope is the main key to classifying large gravitational rock-slope deformations and to understand their development, complex processes and morpho-tectonic control. The term DSGSD is generally used to describe large noncatastrophic slope deformations with small displacement rates but large cumulative deformations, irrespective of the presence of a major sliding plane, and show a large variety of deformation mechanisms (e.g., Dramis \& Sorriso-Valvo, 1994; Agliardi et al., 2001, 2012).

Characteristic morphostructures of a DSGSD are a distinct back scarp, double ridges, large slide blocks, tension cracks, counterscarps (i.e., uphill-facing scarps), grabens, collapsed block fields, and irregular slope profiles with, for instance, slope bulging at the toe (e.g., Zischinsky, 1969; Dramis \& Sorriso-Valvo, 1994). The types and distribution of such morphostructures often distinguish different areas along the slope indicating various types and degrees of deformation and hence supporting the interpretation of complex kinematics. However important these morphostructures are, their origin along slopes in high mountain terrain is often not clearly understood and hence widely discussed. As mentioned by Jomard et al. (2014), the geomorphological expression of morphostructures of a DSGSD is commonly quite similar to neotectonic features. Especially several kilometre-long linear features that expose either an uphill- or a downhill-facing vertical step along the slope, such as a counterscarp, have been interpreted to be related either to tectonic faulting or to gravitational slope deformation. This has sometimes led to a reinterpretation of these features (Thompson et al., 1997; Hippolyte et al., 2006; Li et al., 2010) because some of them can show characteristic features of both origins (Thompson et al., 1997). However, various mechanisms, including gravitational deformation, folding and faulting are described by Li et al. (2010) who have also highlighted the influence of mountain topography on kinematics of deformation. Therein, flexural toppling along subvertical bedding planes is suggested to be the primary origin for a swarm of counterscarps, similar to Hippolyte et al. (2006) who additionally considered the gravitational reactivation of inherited fault structures.

A distinct geomorphological lineament has developed on the mountain Middagstinden in western Norway. In previous studies by Anda et al. (2002) and Olesen et al. (2004) it was interpreted to be the surface expression of a Holocene reverse fault, named the Berill Fault, and to be the first evidence of neotectonic activity in southern Norway. Therefore, neotectonic seismicity was suggested to be the triggering factor for the cluster of rock-slope failures in this area (Blikra et al., 2002). However, more recent regional investigations on neotectonics in Norway have suggested instead a gravitational origin for this lineament (Olesen et al., 2013), which is also in accordance with field studies on that site by Krieger et al.(2013).

This paper presents the results of detailed integrative site investigations on Middagstinden. The findings exhibit and prove the gravitational origin of the geomorphological lineament and reveal the complex deformation mechanisms of the associated DSGSD. The proposed geological model correlates the mechanisms to the various surface deformation features. The findings will be a useful input for future slope-stability investigations and could improve the interpretation of linear features along slopes in other high-mountain areas.

\section{Regional setting}

The study area is located in the upper part of Innfjorddalen valley, western Norway (Fig. 1). The rock-slope instability is situated on the southern slope of Middagstinden, directly above the artificial Berillvatnet Lake. This area was significantly affected by Pleistocene glaciations with strong erosion and postglacial isostatic uplift (Olesen et al., 2013), and the crust still shows a current apparent uplift rate of several $\mathrm{mm} / \mathrm{yr}$ (Dehls et al., 2000). The valley is a typical U-shaped valley with steep 
slopes and a high topographic relief, here with elevations ranging from $370 \mathrm{~m}$ a.s.l. to $1568 \mathrm{~m}$ a.s.l. within a short distance. Large rock-slope failures are common phenomena in this region (Blikra et al., 2002; Saintot et al., 2012; Oppikofer et al., 2015). The deposits of multiple rock-slope failures that are preserved in the lower part of Innfjorddalen indicate postglacial failure activity (Schleier et al., 2013, submitted).

Geologically, this area is part of the Western Gneiss Region (WGR) of Norway. The bedrock consists mainly of Proterozoic gneisses which are locally

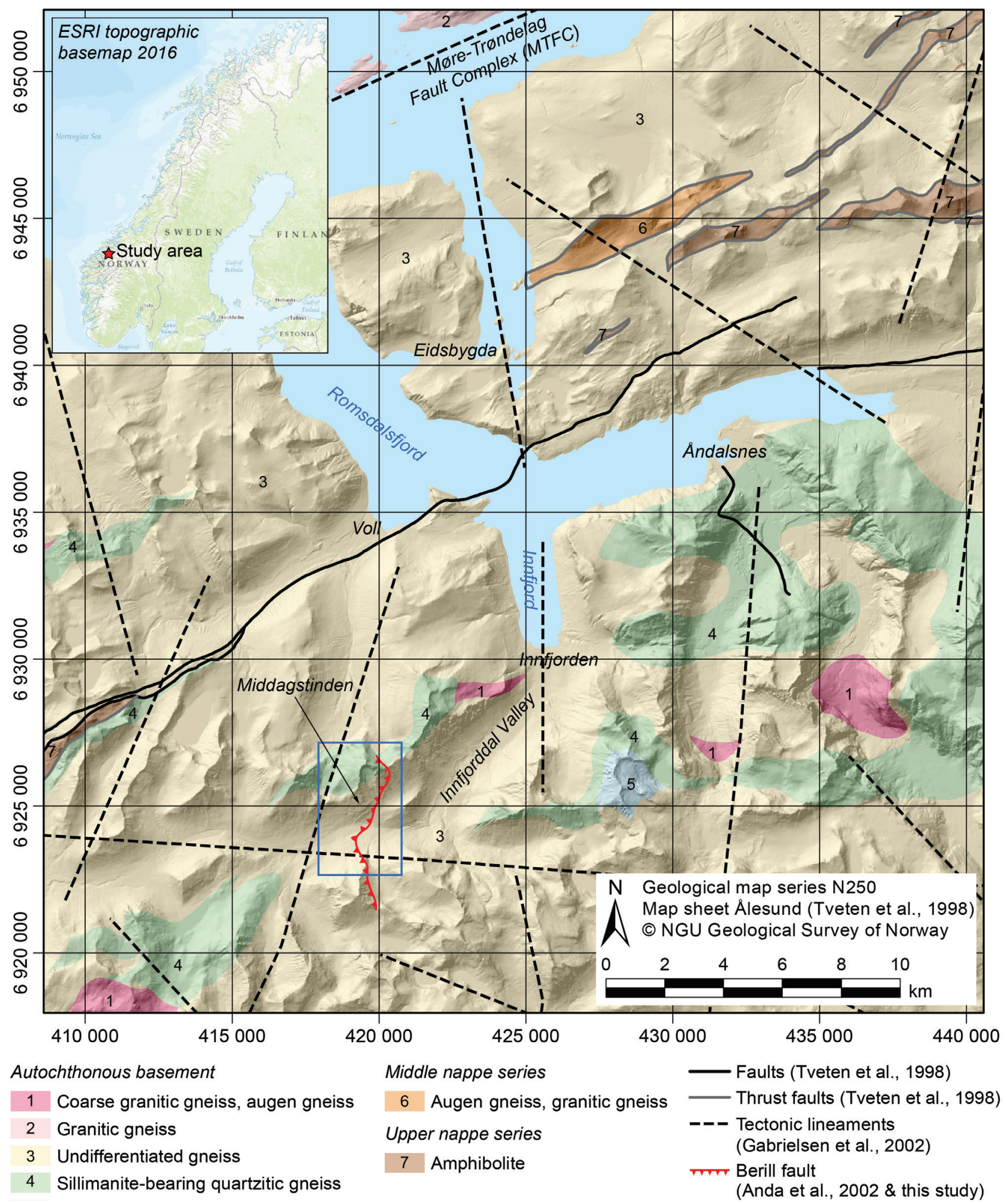

Figure 1. Geological map of the valley Innfjorddalen including the mountain Middagstinden (slightly simplified from Tveten et al., 1998). The blue rectangle delimits the study area. The Berill Fault is highlighted by solid red line. (Coordinate system: WGS1984, UTM Zone 32N). 
covered by oceanic and continental sedimentary rocks. The deformation and metamorphism of the Neo- and Mesoproterozoic rocks took place during the Caledonian orogeny (Nordgulen \& Andresen, 2008). The most prevalent rock types in the WGR are tonalitic and granodioritic gneisses (Hacker et al., 2010). The exposed bedrock in Innfjorddalen is mainly composed of different types of gneisses (Fig. 1) (Tveten et al., 1998). The mountain Middagstinden is mainly composed of undifferentiated, chiefly quartz-dioritic gneisses that show local migmatitic structures. In the uppermost part, there are also quartzitic gneisses that contain sillimanite and partly kyanite. These gneisses have, in general, a welldeveloped foliation that is commonly involved in rockslope failures as sliding surfaces or other main delimiting structures (Henderson \& Saintot, 2011; Saintot et al., 2011). The region also shows a variety of tectonic structures (Fig. 1) that originate from different tectonic episodes, for instance, the Caledonian orogeny and postCaledonian collapse (Tveten et al., 1998; Gabrielsen et al., 2002).

Major tectonic lineaments in this area can be related to the principal sinistral shear component along the MøreTrøndelag Fault Complex (MTFC) with a transtensional strain field that showed activity in Early-Mid Devonian time (Osmundsen et al., 2006). Movements along the associated strike-slip zones with SW extensional shearing led to the exhumation of the basement of the WGR. Correlation of onshore and offshore data shows a diagnostic pattern that confirms this tectonic setting with the MTFC as a major fault and exhibits its importance in the geological development of Mid Norway (Nasuti et al., 2012). These data further exhibit the tendency for crustal movement of the Norwegian margin to show uplift to the east and corresponding downstep to the west (Redfield et al., 2005a). Following Olsen et al. (2007), the major faults related to the MTFC strike approximately NE-SW and were affected by multiphase reactivation during the Phanerozoic. They further mention three main sets of smaller faults that strike E-W, N-S and NW-SE, with the N-S and NWSE faults probably relating to Caledonian extension by differential sinistral movement. Furthermore, Redfield et al. (2005b) proposed that normal reactivation of the MTFC contributed to the latest Cretaceous-Cenozoic uplift of western Norway and suggested a vertical crustal uplift in the order of $2-3 \mathrm{~km}$.

\section{Materials and Methods}

\section{Field investigations and used data}

Detailed geomorphological and structural field mapping was carried out at the unstable rock slope of Middagstinden to characterise the different areas within the slope and to identify geomorphological features and tectonic structures that delimit the rock-slope instability.
Field mapping was supported and improved by remote sensing data such as orthophotos with a grid size of $0.5 \mathrm{~m} \times 0.5$ $\mathrm{m}$ and an airborne laser scanning (ALS) derived digital elevation model (DEM) with a grid size of $2 \mathrm{~m} \times 2 \mathrm{~m}$. Orthophotos and especially the DEM derivatives such as hillshade and slope angle enable a better overview over the whole site, and provide an improved identification of prominent geomorphological structures throughout the instability.

\section{Structural measurements and kinematic analyses}

Detailed structural field mapping was performed at 35 locations over the entire study area. In total, 1126 measurements were taken by compass to determine the orientation of discontinuity surfaces. Spacing, persistence and roughness of discontinuities were also recorded at these locations following the classifications of ISRM (1981) as presented in Wyllie \& Mah (2004). Additionally, structural data were collected by a terrestrial laser scanning survey (Krieger et al., 2013).

Structural datasets were analysed using the software Dips (Rocscience, 2015). Cluster analysis was conducted to determine mean orientations and $1 \sigma$ variability of the main discontinuity sets. Additionally, field measurements were grouped into 12 representative morphological areas within the slope, such as coherent rock blocks, to determine the mean orientations of discontinuity sets. Results were plotted in equal-area, lowerhemisphere stereonets, and depicted as great circles, pole points and $1 \sigma$ variability cones. Values are presented with dip direction/dip angle.

Furthermore, kinematic feasibility tests for planar, wedge and toppling failures (Wyllie \& Mah, 2004) were carried out based on the field measurements. For analyses, the slightly changing topography along the slope has to be taken into consideration. Surface analyses of the DEM show that the slope angle is rather constant with a mean value of $35^{\circ}$, but the slope aspect changes from the eastern $\left(\sim 151^{\circ}\right)$ to the western $\left(\sim 182^{\circ}\right)$ part of the slope. Therefore, a mean slope orientation of $175^{\circ} / 40^{\circ}$ was used. A friction angle of $20^{\circ}$ along discontinuity surfaces and lateral limits of $30^{\circ}$ were applied for kinematic analyses to obtain conservative results. These values are in accordance with recommendations on the hazard and risk classification of large unstable rock slopes in Norway by Hermanns et al. (2012a), and account for the complex structures of large rock-slope failures and the variability in slope orientation.

\section{Displacement measurements}

Displacements within the rock-slope instability have been measured periodically using the differential global navigation satellite system (dGNSS) technique. The monitoring network consists of one fixed point in a stable part above the main scarp and four rover points that 
are installed within the instability. This setup enables us to derive a vector network indicating the relative point movement. On Middagstinden, annual measurements were conducted between 2008 and 2015, except in 2012 and 2014. Measurements provide 2D horizontal and vertical displacements relative to the first measurement. Average uncertainties on individual measurements range from $1.9-2.2 \mathrm{~mm}$ in the horizontal direction and 2.9-3.3 $\mathrm{mm}$ in the vertical direction. By regression analyses of the measured displacements against time, the average displacement rate $(\mathrm{mm} / \mathrm{yr})$ and displacement direction (trend/plunge) can be determined. Using this regression analysis reduces the uncertainties on the yearly displacement rates to $0.2-0.3 \mathrm{~mm} /$ year horizontally and $0.5-0.7$ $\mathrm{mm} /$ year vertically. A displacement is considered to be significant when it is larger than these uncertainties and if it follows a coherent trend over several measurements (Böhme et al., 2012).

\section{Geophysical investigations}

The geoelectric resistivity tomography (ERT) technique was applied to investigate the subsurface of the geomorphological lineament to detect the continuation and orientation of the proposed fault structure. Three 2D geoelectric resistivity profiles were measured at the lower slope and the valley bottom using the Lund system (Dahlin, 1993), a multi-gradient electrode configuration and an ABEM SAS Terrameter 4000 (ABEM, 1999) instrumentation. Electrode separation was set at $2 \mathrm{~m}$ in profile $1,2.5 \mathrm{~m}$ in profile 2 and $1 \mathrm{~m}$ in profile 3 giving a penetration depth of $25 \mathrm{~m}$ and $60 \mathrm{~m}$, respectively. This method is proven to be a powerful tool for mapping drift deposits and fracture zones in bedrock (Solberg et al., 2008; Rønning et al., 2009, 2014). In addition, two trenches were opened down to glacial deposits or bedrock on the valley bottom where the geoelectric profile P3 suggests the position of the fault, to study the deformation of soft sediments.

\section{Results}

Preliminary results according to the rock-slope instability at Middagstinden have already been described and discussed in Krieger et al. (2013). However, these data and the interpretation were improved by detailed structural cluster analyses, further analyses and interpretations of orthophotos and DEMs, additional dGNSS displacement measurements, as well as a new geological model of the instability.

\section{Geomorphology and morphostructures}

Several main areas (numbered 1 to 11 in Fig. 2A) can be distinguished within the rock-slope instability and are characterised by different morphologies and by the types and amount of deformation (Fig. 2). All of the described areas that show deformation are located to the northwest of and above the distinct geomorphological lineament of the Berill Fault. The areas can be roughly grouped and distinguished as the northeastern instability (1 to 4 ), the main instability (5 to 10 ) and the small separate western instability (11).

\section{Northeastern instability (1 to 4 )}

Top of Middagstinden (1 and 2): The large niche (1) is limited at the back by a steep and high rock face. Small failures such as rock fall are likely for this fractured steep rock slope. Area (2) is covered by debris and talus material and shows moraine deposits indicating the existence of a previous cirque glacier that could have formed the niche.

Upper northeastern part (3): The niche of area 1 is limited towards the northeast by fractured bedrock material of area 3 that shows a relatively steep slope topography. Below a main scarp that delimits this area to the top, there is a set of subparallel distinct counterscarps. Both of those structures are subparallel to the observed foliation.

Lower northeastern part (4): This area is covered by surficial sediment deposits and shows counterscarps that strike NE-SW parallel to the counterscarps and the main scarp of the main instability (areas 5 to 10 ) (Figs. $3 \& 4 \mathrm{~B}$, F). Furthermore, lateral moraine deposits that are associated to the Younger Dryas cirque glacier are preserved and active avalanche tracks and associated debris cones were identified. The counterscarps are around $3 \mathrm{~m}$ deep. They partly deform the surficial deposits (including the lateral moraines) and are partly filled by colluvium (e.g., avalanche debris) (Fig. 4D). This morphological area is clearly limited toward southeast by a prominent geomorphological lineament formed by the Berill Fault (Anda et al., 2002). This lineament strikes SSW-NNE with a $30^{\circ}$ oblique angle to the SE-facing slope and can be traced as a 3-4 m high convex morphological step in the topography. The lineament is around $1.4 \mathrm{~km}$ in length but disappears in the valley bottom (Fig. 2).

\section{Main instability (5 to 10)}

Several subareas are distinguished within the main rockslope instability (Figs. $2 \& 3$ ). Besides the morphological areas, rather coherent blocks of bedrock were identified within the instability showing different styles and degrees of deformation.

Main scarp and sliding surface (5): The back-bounding limit of the main instability is formed by its main scarp (Fig. 3). The exposed sliding surface is represented mainly by the foliation and subparallel surfaces (Fig. 4B, C). Scarp offset was measured based on DEM and orthophoto inspections. The mean horizontal length of the exposed sliding surface is approximately $50 \mathrm{~m}$ showing 

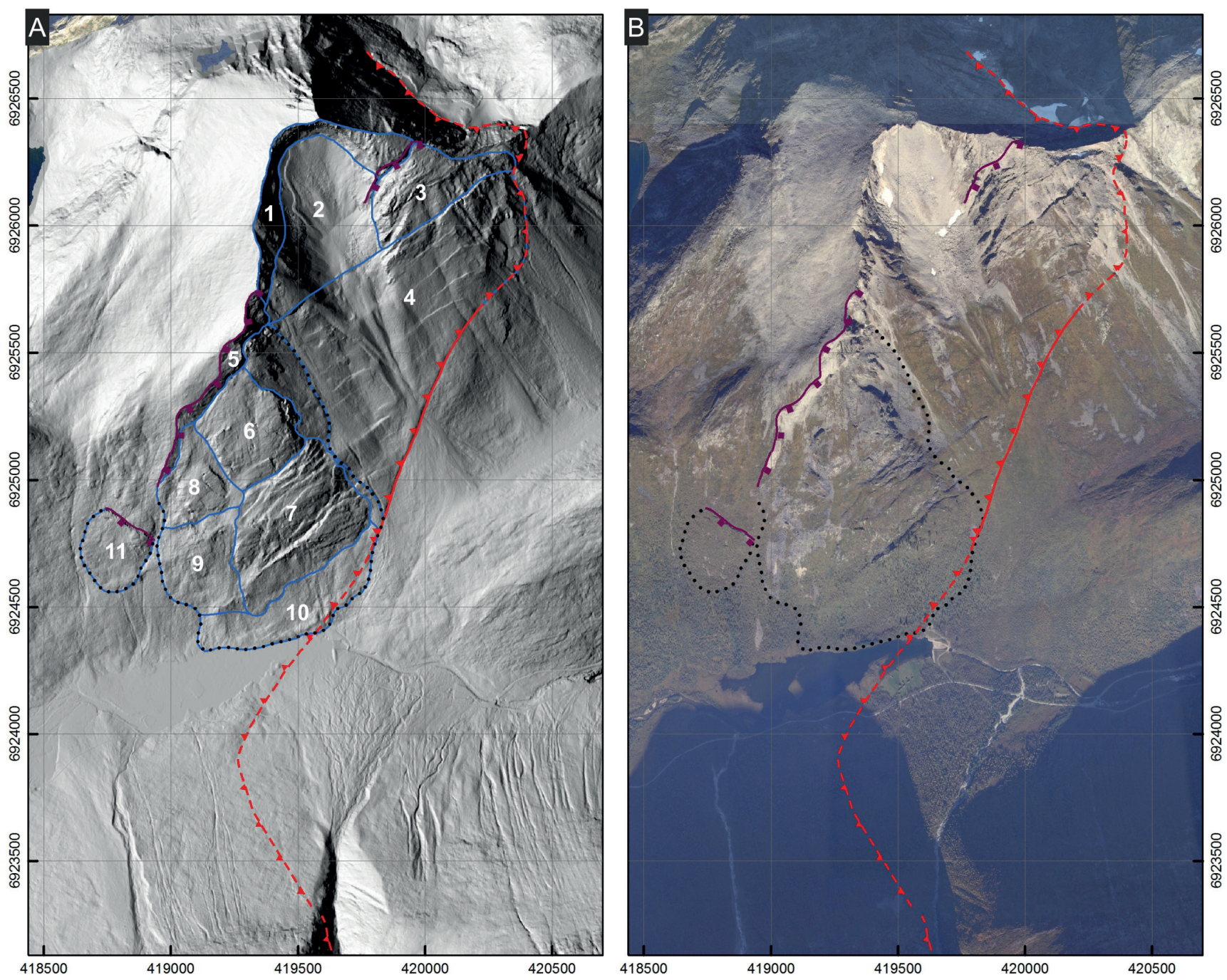

Figure 2. Overview map of Middagstinden. (A) hillshade and (B) orthophoto, showing the extent of the main rock-slope instabilities (black dotted lines), the associated main scarps (purple lines), and the trace of the fault lineament (red line). Additionally, the geomorphological areas as described in the text are outlined in subfigure (A). (Coordinate system: WGS1984, UTM Zone 32N).

smaller values at its southwestern limit. The mean height of the scarp is around $60 \mathrm{~m}$, resulting in a total offset of around $80 \mathrm{~m}$.

Upper eastern part (6): This area is composed of several rather coherent slide blocks that cover an area of around $130000 \mathrm{~m}^{2}$ (Fig. 3). The rocks are fractured (Fig. 4B, D) and the slide blocks are mainly delimited by the major joint sets and lack surficial sediment cover. Small-scale rock-fall activity is evident at the lateral and frontal margins where large blockfields have developed with blocks up to several metres in size. This area shows the lowest amount of internal rock deformation throughout the instability.

Lower eastern part (7): The main morphological characteristic of this area is the prominent array of counterscarps formed by fractured bedrock (Fig. 4D, F). Their occurrence delimits this area from area 6 . These linear features strike mainly NE-SW which is subparal- lel to the counterscarps in area 4 and furthermore subparallel to the foliation (Fig. 3). Morphologically, these counterscarps are graben-like structures that are up to $20 \mathrm{~m}$ deep and 10-50 m wide. High rock-fall activity is present at the associated rock faces. Hence, the scarps are filled with metre-size blocks that masks their real depth. This area can be divided into two subareas; an area of upper counterscarps (7a) and one of lower counterscarps (7b), respectively (Fig. 3). Counterscarps are more frequent in the upper subarea $7 \mathrm{a}$. Here, six large counterscarps were mapped within a horizontal distance of $125 \mathrm{~m}$ that are tens of metres deep and between 100

Figure 3. Map of the rock-slope instability of Middagstinden, showing the geomorphological characteristics and areas of deformation. The labels $A$ to $K$ mark the areas determined for structural analyses as presented in Fig. 5. Location of the field photo of Fig. 6 is marked by a yellow arrow. (Coordinate system: WGS1984, UTM Zone 32N). 


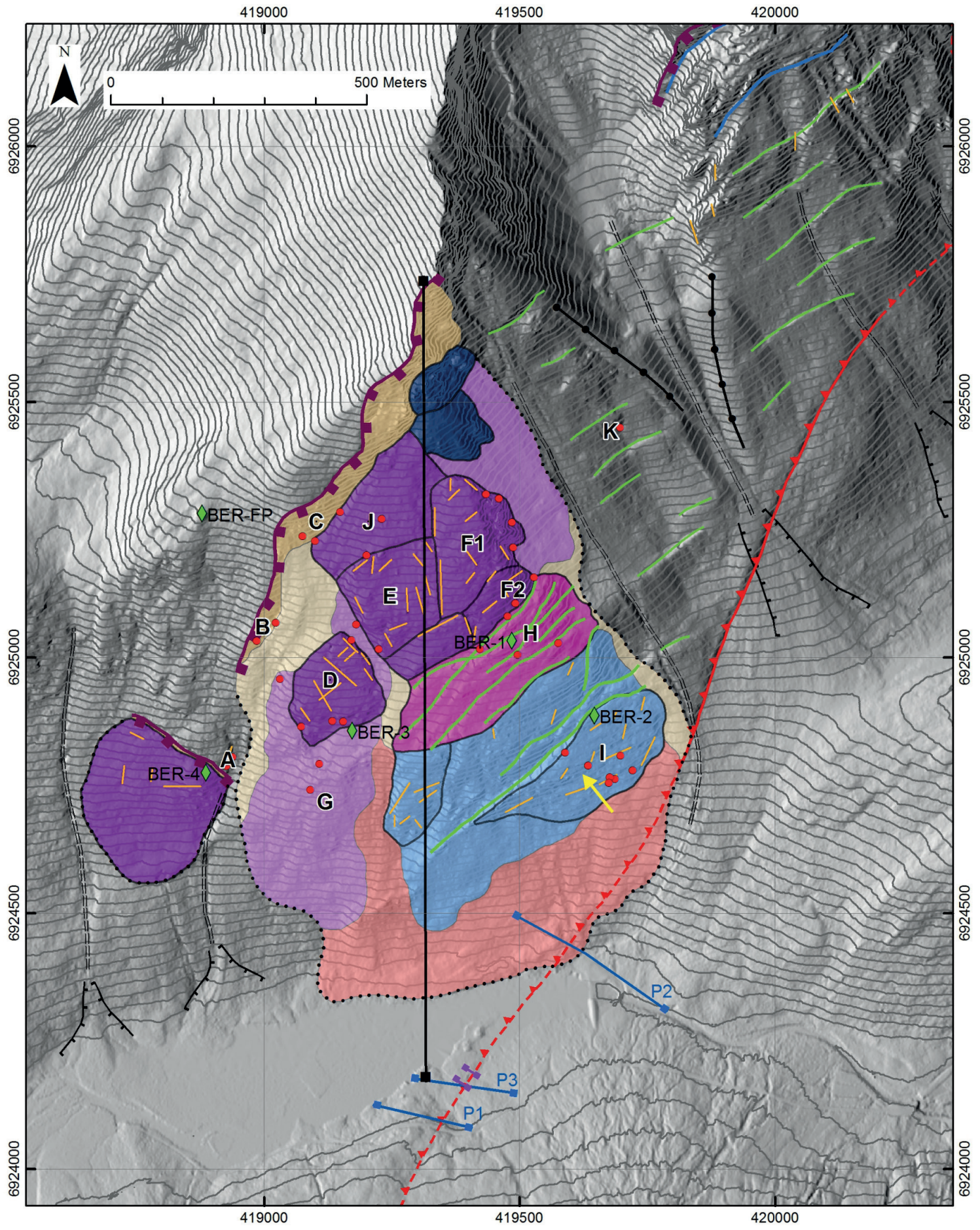

Legend

investigations

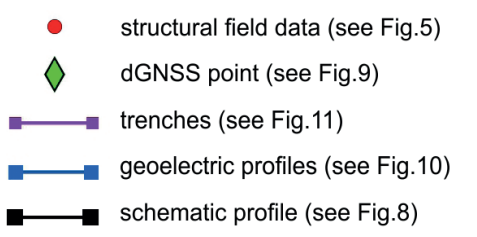

geomorphological characteristics

..... limit of instability

counterscarp

scarp

- joint

_ $\Delta$ _ _ fault trace, assumed

A fault trace, mapped

$===$ avalanche track

debris cone

$\longrightarrow$ moraine ridge main areas within instability

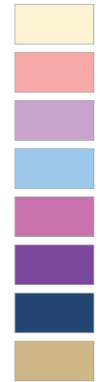

shallow talus cover

talus of fractured slide blocks

fractured and collapsed slide blocks

lower counterscarps

upper counterscarps

coherent slide blocks

fractured slide blocks

bare rock (sliding surface) 
and $400 \mathrm{~m}$ long. In contrast, area $7 \mathrm{~b}$ shows only two large counterscarps within a horizontal distance of $150 \mathrm{~m}$ that are also tens of metres deep but range in length from 350 $\mathrm{m}$ to $550 \mathrm{~m}$. In this lower subarea $7 \mathrm{~b}$, two rather coherent slide blocks can also be identified. One of these blocks marks the lowermost limit of the lower eastern part. Area 7 shows a greater degree of internal rock deformation than area 6. Bulging of the slope, that is, a slightly convex slope profile, is a characteristic feature of the topography in this lower area of the slope.

Upper western part (8): This area is limited by the main scarp and the lateral limit of the coherent slide blocks of area 6 . The upper part, directly below the exposed sliding
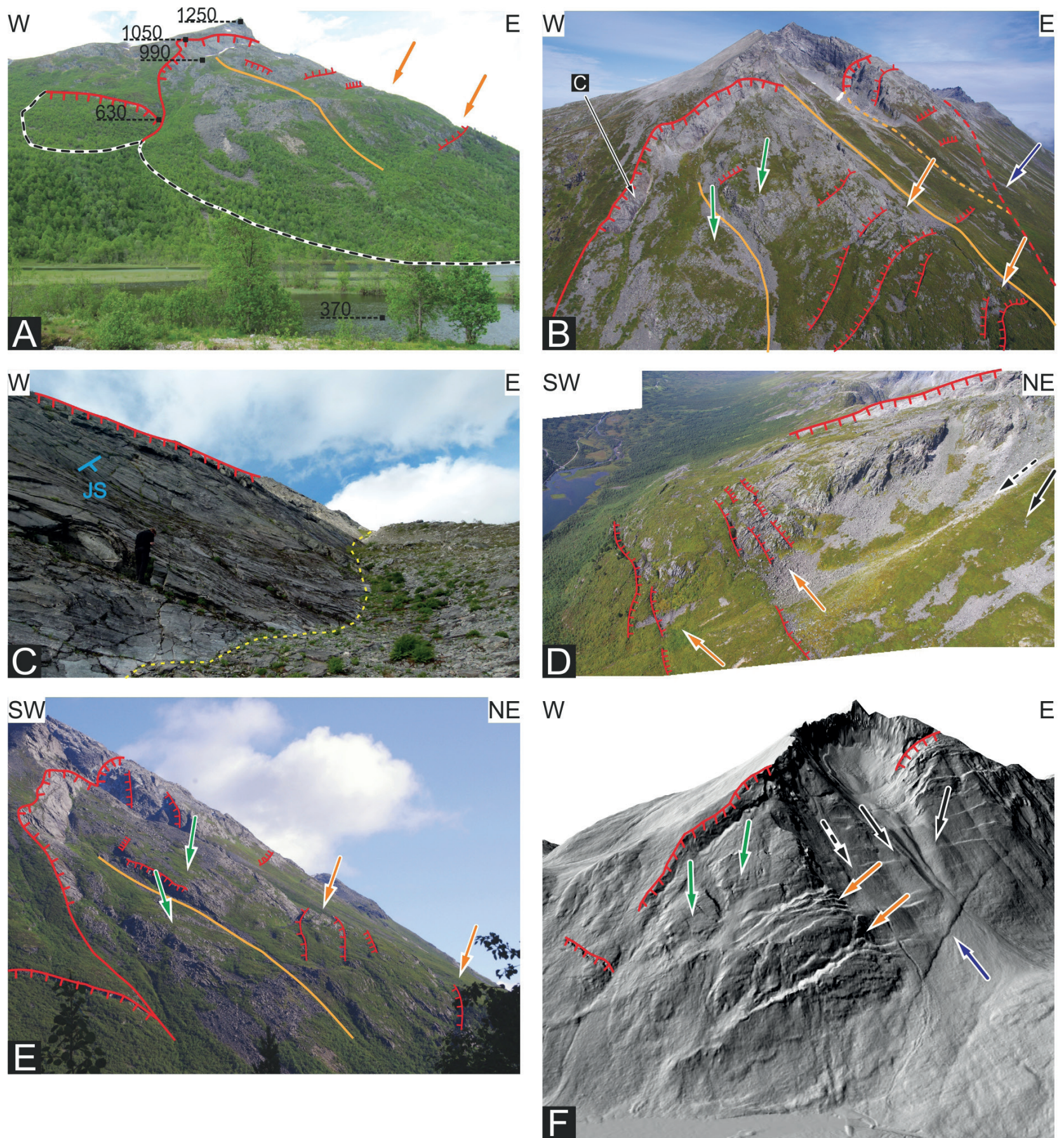

Figure 4. Photographs and oblique view of Middagstinden, showing geomorphological characteristics of the rock-slope instability (red linemain scarp and scarp, red dashed line and blue arrow - trace of the fault, black dashed line - delimitation of rock-slope instabilities, orange line - delimitations within the instabilities, orange arrows - counterscarps, green arrows - coherent slide blocks, black arrows - moraine ridges, black dashed arrow - avalanche track). For scale and areas within the instability, refer to Figs. 2 and 3. (A) Overview from the valley bottom; the labels mark elevations in $m$ a.s.l. (B) Upper part of the main instability. (C) Main sliding plane subparallel to the foliation; the location is marked in subfigure (B). (D) Eastern part of the main instability. (E) Western part of the main instability. (F) Oblique 3D view of the hillshade. The marked trace of the fault forms a $4 \mathrm{~m}$ convex topographic step running oblique to the slope. 
surface, is characterised by a shallow cover of talus. One distinct coherent slide block with defined lateral limits is located in the centre of this area (Fig. 3). This block is composed of fractured bedrock, similar to the blocks in area 6. The open cleft between this block and the blocks of area 6 indicates a slight counterclockwise rotation compared to area 6 (Fig. 4B, E, F). Besides this large slide block, many single and highly fractured bedrock outcrops, that are small slide blocks, are found randomly distributed within this area, especially at the western and frontal limit. Small-scale rock fall occurs at the margins of these blocks. These slide blocks are surrounded by large blockfields of fractured and collapsed slide blocks that are composed of metre-size angular boulders. The lack of repositioning structures and highly fractured bedrock outcrops within the deposits suggest in situ fragmentation rather than just rock-fall activity. This area shows the highest degree of internal rock deformation throughout the instability.

Lower western part (9): This area is mainly characterised by large blockfields with metre-size boulders of fractured and collapsed slide blocks that show local repositioning structures (Figs. $3 \& 4 \mathrm{~A}$ ). Besides that, areas lacking large boulders but with talus of fractured slide blocks were also identified. In some areas of the loose rock deposits with smaller boulders and an increased amount of soil, surficial mass movements, such as shallow debris flows, also occur. Bedrock outcrops can be found in only a few locations within the blockfields, and are highly fractured and weathered. An accumulation of such outcrops embedded in large blockfields is observed at the transition to area 8 . Together with the upper part, this area shows the greatest degree of rock deformation and fragmentation within the instability.

Lowermost part (10): The area that forms the lower limit of the main instability is characterised by talus material with mainly metre-size boulders of the fractured and partly collapsed slide blocks. This material could be mixed up with previous pre-failure talus slope material. No large rock outcrops or large slide blocks are found within this area. However, the deposits show lobate deformation structures (Fig. 4A, E, F), such as compression ridges, at the lowermost margin of the instability.

\section{Western instability (11)}

The western instability (area 11) is a small, separate rock-slope instability located west of the main instability (Figs. $3 \& 4$ A, E, F). This rather coherent slide block shows less distinct fractures at the surface and is delimited by a NW-SE-striking back scarp. This scarp is about 5-10 m wide and from several metres up to tens of metres deep.

\section{Structural analyses}

Four main discontinuity sets that are developed throughout the whole slope were identified by structural field measurements (Table 1). The observed main discontinuities are the metamorphic foliation (JS), a fault set (JF) and two major joint sets (J1, J2). An additional minor joint set and another randomly varying joint set (J3) are found in some of the areas. $1 \sigma$ variability of mean orientations is generally between 16 and $20^{\circ}$ (Table 1). With reference to the geomorphological areas within the main instability (Fig. 3), variations of the mean orientations and $1 \sigma$ variabilities are identified for the representative areas A to K (Fig. 5).

\section{Foliation (JS)}

The mean orientation of the foliation (JS) is $158^{\circ} / 49^{\circ} \pm$ $17^{\circ}$, and varies over the whole area of the main instability. Within areas 6 and 8, the foliation forms distinct smooth and planar-undulating discontinuity surfaces with high persistence, close to moderate spacing and little variability in orientation. The foliation forms prominent structures, both the main scarp and the counterscarp that limits area 6 . In area 5, groove marks with a trend/plunge of $138^{\circ} / 42^{\circ} \pm 16^{\circ}$ are found on the exposed sliding surface that is formed by the foliation. However, the foliation shows higher variability in orientation, higher spacing and smaller persistence within the lower parts of the instability, especially in the area 7 with the counterscarps. Over the slope, the dip direction varies between SW and SSW with dip angle between $40-90^{\circ}$ (Fig. 5), which is due to folding in $\mathrm{cm}$ - but also $\mathrm{m}$-scale.

\section{Fault set (JF)}

A mean orientation of $271^{\circ} / 43^{\circ} \pm 16^{\circ}$ was determined for the main joint set (JF). This discontinuity set shows high, and in part even very high persistence and the spacing varies very much depending on the area. In some places the outcrops recur on the surface at metre scale, whilst in other parts of the area they are absent. In the area of counterscarps (7), the JF dips at about $16^{\circ}$ shallower than farther up the slope. Generally, the roughness can be described as slickensided planar. The surfaces of this discontinuity set show a strong lineation with trend/plunge of $245^{\circ} / 31^{\circ} \pm 11^{\circ}$, and a distinct quartz-feldspar remineralisation with frequent break-offs that indicate a normal fault movement at depth (Fig. 6A). These lineations do not occur continuously on all surfaces of the JF fault set and the planes are partly undulating with varying orientations (Fig. 5). The mean orientation shows that the fault set strikes up to $20^{\circ}$ oblique to the observed SSWNNE-striking geomorphological lineament.

\section{Joint sets (J1, J2 and J3)}

Two prominent major joint sets (J1, J2) are developed throughout the slope. Both dip steeply with mean orientations of $309^{\circ} / 77^{\circ} \pm 16^{\circ}$ and $039^{\circ} / 84^{\circ} \pm 20^{\circ}$, respectively. Additionally, a rather variable joint set (J3) showing a mean orientation of around $019^{\circ} / 45^{\circ} \pm 15^{\circ}$ can be found 

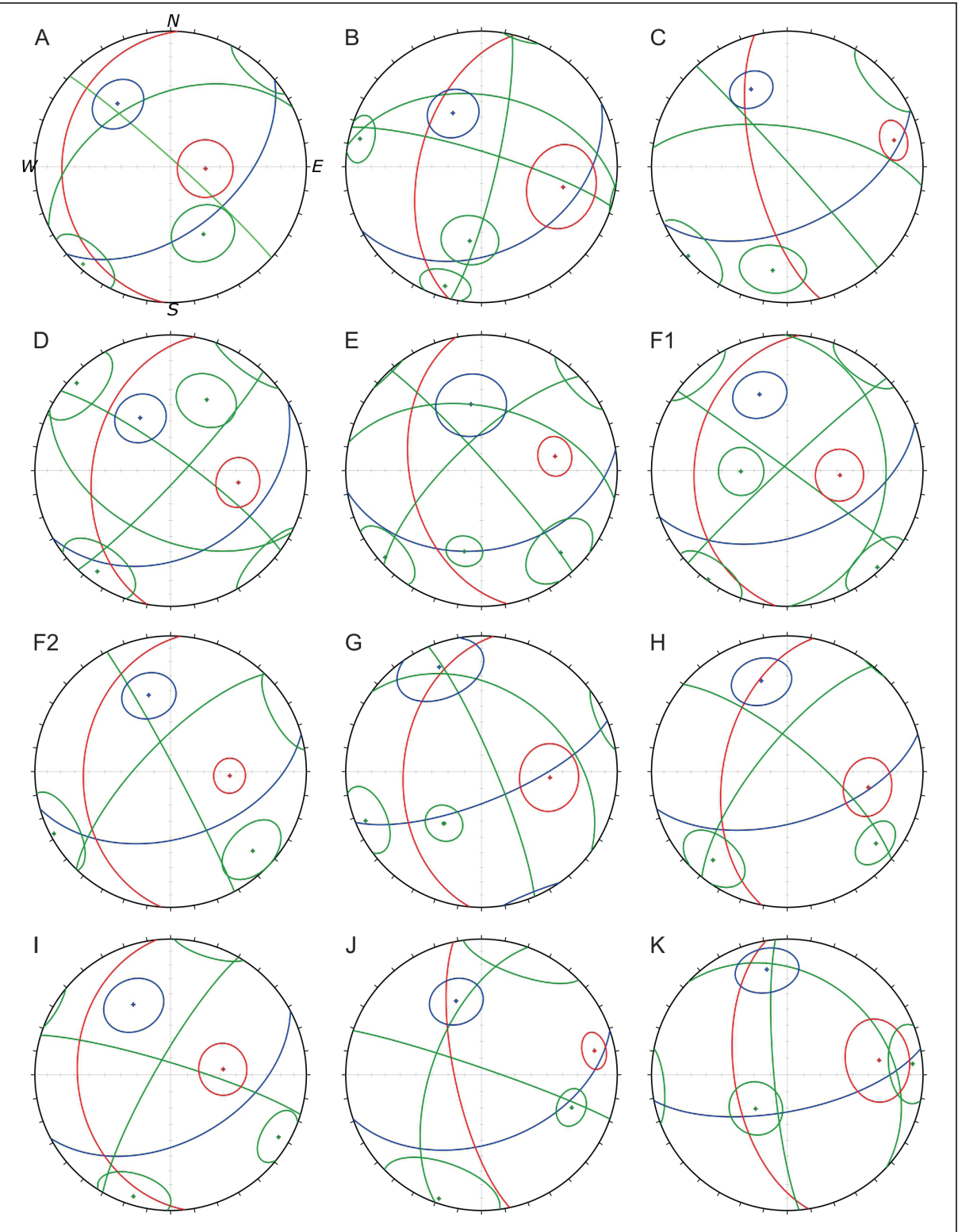

Figure 5. Schmidt net plots of main discontinuity sets at various areas along the slope of Middagstinden (equal area, lower hemisphere, north upwards). The discontinuities are indicated by different colours (blue - foliation, red - fault, green - major joint set), and the circles display the 1 $\sigma$ variability cones of their mean orientations. The values are derived by cluster analysis of the structural field measurements conducted for the separate areas labelled A to K. For locations of structural field measurements and areas, refer to Fig. 3.

Table 1. Summary of the main discontinuity sets of the rock-slope instability on Middagstinden (modified following Krieger et al., 2013). The values are the mean orientation $\pm 1 \sigma$ variability derived by cluster analyses of TLS-derived pole vector selections $(n=22124)$ and structural field measurements $(n=$ 1126 planes), respectively. Discontinuity characteristics as observed in the field are expressed qualitatively with reference to the classification of Wyllie \& Mah (2004). JF shows lineations with trend/plunge of $245^{\circ} / 31^{\circ} \pm 11^{\circ}$. Groove marks with trend/plunge of $138^{\circ} / 42^{\circ} \pm 16^{\circ}$ are observed on the JS below the main scarp area. For locations of structural field measurements, refer to Fig. 3.

\begin{tabular}{|c|c|c|c|c|c|}
\hline \multirow[t]{2}{*}{ Type } & \multicolumn{2}{|c|}{ Orientation (dip direction/dip) } & \multirow[t]{2}{*}{ Spacing } & \multirow[t]{2}{*}{ Persistence } & \multirow[t]{2}{*}{ Roughness } \\
\hline & $\operatorname{TLS}\left(^{\circ}\right)$ & Field $\left({ }^{\circ}\right)$ & & & \\
\hline $\begin{array}{l}\text { Fault } \\
\text { (JF) }\end{array}$ & - & $271 / 43 \pm 16$ & Moderate-extremely wide & High & $\begin{array}{l}\text { Slickensided, } \\
\text { planar }\end{array}$ \\
\hline $\begin{array}{l}\text { Foliation } \\
\text { (JS) }\end{array}$ & $160 / 50 \pm 11$ & $158 / 49 \pm 17$ & Close-moderate & High & $\begin{array}{c}\text { Smooth, } \\
\text { planar-undulating }\end{array}$ \\
\hline $\begin{array}{l}\text { Joint set } \\
\text { (J1) }\end{array}$ & $315 / 80 \pm 8$ & $309 / 77 \pm 16$ & $\begin{array}{l}\text { Wide- } \\
\text { very wide }\end{array}$ & High & $\begin{array}{c}\text { Rough, } \\
\text { planar (undulating) }\end{array}$ \\
\hline $\begin{array}{l}\text { Joint set } \\
\text { (J2) }\end{array}$ & $048 / 81 \pm 14$ & $039 / 84 \pm 20$ & $\begin{array}{l}\text { Wide- } \\
\text { very wide }\end{array}$ & High & $\begin{array}{c}\text { Rough, } \\
\text { planar (undulating) }\end{array}$ \\
\hline $\begin{array}{l}\text { Joint set } \\
\text { (J3) }\end{array}$ & - & $019 / 45 \pm 15$ & $\begin{array}{c}\text { Wide- } \\
\text { extremely wide }\end{array}$ & $\begin{array}{l}\text { Very low- } \\
\text { medium }\end{array}$ & $\begin{array}{l}\text { Smooth-rough, } \\
\text { undulating }\end{array}$ \\
\hline
\end{tabular}



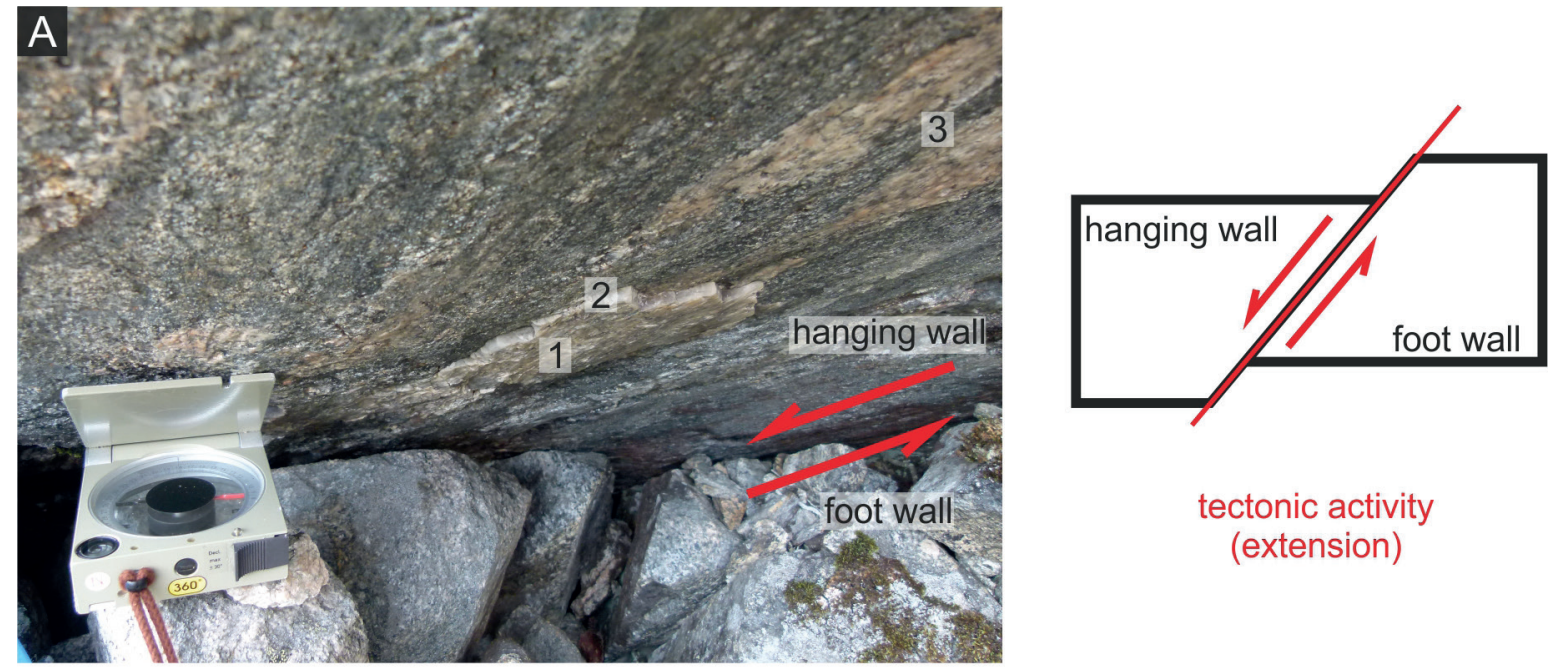

tectonic activity (extension)
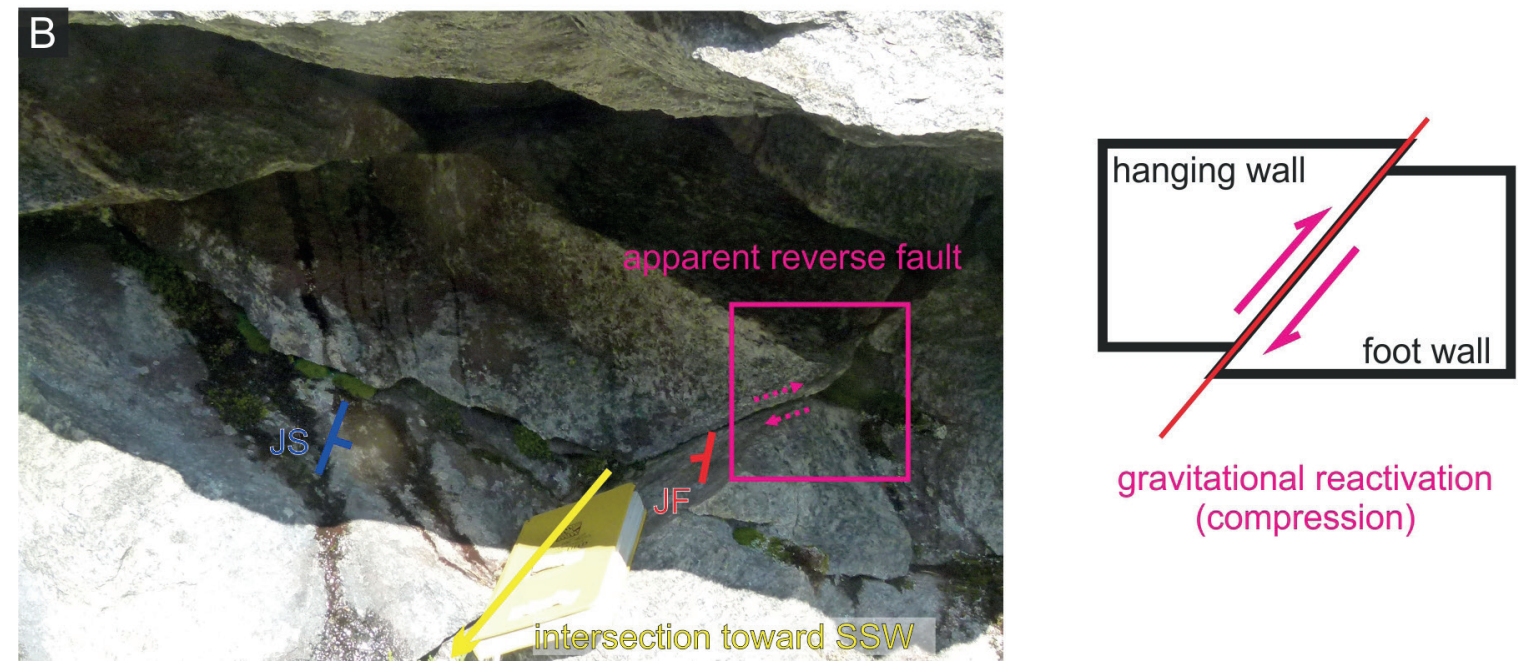

gravitational reactivation (compression)

Figure 6. Photographs of the fault plane and the wedge sliding along its intersection with the foliation observed on Middagstinden. Location of the photos is marked with a yellow arrow in Fig. 3. (A) Fault plane JF showing (1) quartz remineralisation, (2) distinct break-offs, and (3) lineations which indicate a normal fault movement with tectonic activity at greater depth (simplified sketch on the right side). (B) Wedge sliding along the intersection between JF and the foliation JS (yellow arrow - field measurement with trend/plunge of $2011^{\circ} / 21^{\circ}$ ) as observed in a small-scale field example. The sliding has given rise to the geomorphological structure of the apparent reverse fault because of near-surface gravitational reactivation (simplified sketch on the right side). For mean orientations of the discontinuity sets along the slope, refer to Table 1.

in some areas but is more common in the upper middle part of the slope (areas B, D, E and F1). J1 and J2 show wide to very wide spacing with high persistence, and if detectable, J3 shows wide to extremely wide spacing with very low to medium persistence. The surface roughness of the joint sets $\mathrm{J} 1$ and $\mathrm{J} 2$ can be described as generally rough, planar and in places undulating, whereas that of $\mathrm{J} 3$ generally varies between smooth and rough, undulating. At the main scarp, these joint sets do not occur as frequently as in the deforming parts, and their persistence is much lower. Most of the prominent structures, such as large fractures, cracks, linear features or slide block delimitations are controlled by J1 and J2. For instance, the counterscarps are mainly defined by the J1 set, and slide block D is delimited from block E by J2.

\section{Kinematic analyses}

Kinematic analyses conducted with the mean orientations of discontinuity sets for the whole slope show that various types of failure are kinematically feasible (Fig. 7). A wedge failure is highly feasible as discontinuity sets show various intersections that fall within the wedge failure envelope. The critical intersections are JS $\cap J F$ and $\mathrm{JS} \cap \mathrm{J} 1$ for the mean slope orientation of $175^{\circ} / 40^{\circ}$. In the case of the slightly steeper slope angle $\left(\sim 50^{\circ}\right)$, intersec-

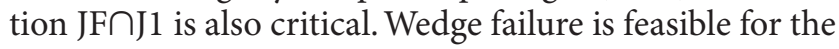
mean slope orientation but also for the changing aspects along the slope that are ranging from SE in eastern areas to $S$ in the western part. Toppling failure would be kinematically feasible along joint set J1 when the slope aspect is more to the southeast. Planar failure along JS is kine- 


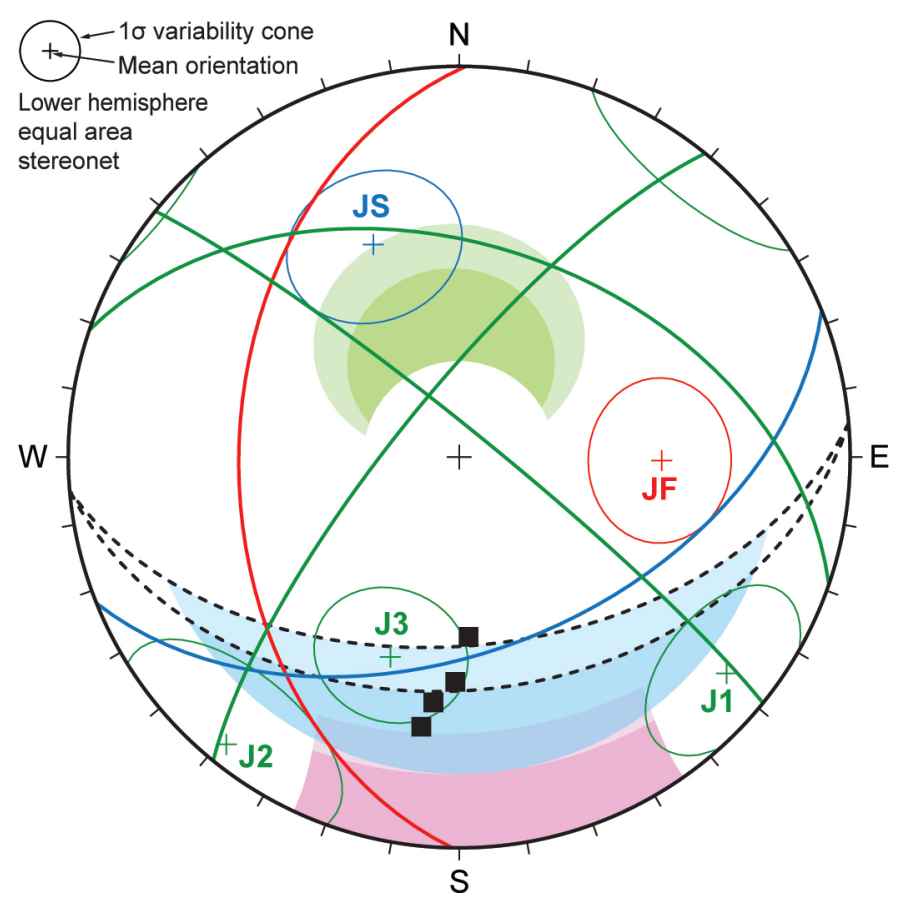

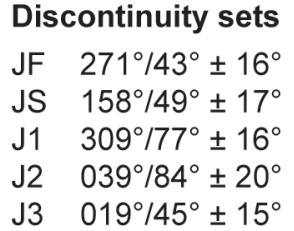

Kinematic test

Topography $\quad 175^{\circ} / 40^{\circ}$ or $175^{\circ} / 50^{\circ}$

Friction angle $20^{\circ}$

Envelope of kinematic feasibility for different slope angles... $40^{\circ} 50^{\circ}$

$\begin{array}{ll}\text { Planar sliding } & \text { partly possible on } \mathrm{JS} \\ \text { Wedge sliding } & \text { possible on } \mathrm{JS} \wedge \mathrm{JF}, \mathrm{JS} \wedge \mathrm{J} 1 \\ \text { Toppling } & \text { partly possible on } \mathrm{J} 1\end{array}$

Figure 7. Schmidt net plot of main discontinuity sets on Middagstinden. The discontinuities are the foliation (JS), the fault (JF), and two major (J1 and J2) and one random (J3) joint set (see Table 1). The values are derived by cluster analysis of the structural field measurements conducted for the whole slope. The figure shows failure envelopes of kinematic feasibility tests using the mean orientations and a lateral limit of $30^{\circ}$. The black dashed line marks the slope, and the black rectangles show the orientations of the dGNSS displacement vectors.

matically feasible for the observed slope orientations when using a slope angle of $50^{\circ}$.

A schematic geological model for the DSGSD was established based on the geomorphological and structural findings (Fig. 8). This 2D model is based on a topographic profile that is drawn in the direction of the movement (Fig. 3), and shows the apparent dip of JS and JF in the profile direction. The intersection line between these two discontinuity surfaces is critical according to the kinematic analyses (trend/plunge of $218^{\circ} / 29^{\circ}$ ). However, this intersection line is not exposed on the slope but lies below the valley bottom.

\section{dGNSS displacement measurements}

The displacement measurements using periodic dGNSS surveys reveal that all rover points (BER-1, BER-2, BER-3 and BER-4) show significant displacements in the horizontal direction, ranging between 4.0 and $13.2 \mathrm{~mm} / \mathrm{yr}$ with an error of $0.2-0.3 \mathrm{~mm} / \mathrm{yr}$ (Table 2). All rover points are also significant in the vertical direction, ranging from -2.7 to $-17.4 \mathrm{~mm} / \mathrm{yr}$ with an error of $0.5-0.7 \mathrm{~mm} / \mathrm{yr}$. The negative displacements indicate downward-directed movement. The resulting $3 \mathrm{D}$ displacements range between 4.8 and $21.9 \mathrm{~mm} / \mathrm{yr}$ with an error of around $0.4-0.5 \mathrm{~mm} /$ yr. The highest $3 \mathrm{D}$ displacement rates were determined for BER-4 (21.9 $\pm 0.4 \mathrm{~mm} / \mathrm{yr})$, located on the small, western instability. It shows a downward S-directed movement towards $178^{\circ} / 53^{\circ}$ (trend/plunge; Fig. 9). All of the other rover points (BER-1, BER-2 and BER-3) located on the main instability also show movement to the south, but with varying displacement rates and plunge angles. BER-1 located in area $7 \mathrm{a}$ moves with $8.1 \pm 0.5 \mathrm{~mm} / \mathrm{yr}$ towards $182^{\circ} / 42^{\circ}$ (Fig. 9), while BER-2 in area $7 \mathrm{~b}$ moves slower and with a shallower plunge angle $(4.8 \pm 0.5 \mathrm{~mm} /$ yr towards $189^{\circ} / 32^{\circ}$; Fig. 9$)$. BER-3 located in area $8(8.0$ $\pm 0.5 \mathrm{~mm} / \mathrm{yr}$ towards $186^{\circ} / 37^{\circ}$ ) has a similar velocity and direction as BER-1 (Fig. 9). These dGNSS measurements indicate a coherent movement of the upper part of the main instability with approximately $\sim 8 \mathrm{~mm} / \mathrm{yr}$ towards the south with plunge angles of around $37-42^{\circ}$, while the lower part moves more slowly and is less steep $(\sim 5 \mathrm{~mm} / \mathrm{yr}$ towards the south with plunge angles of $\left.32^{\circ}\right)$. This suggests a change in deformation mechanism between the different areas, more precisely between the subareas $7 \mathrm{a}$ and $7 \mathrm{~b}$. This change will be further explored in section 5.1.

\section{Geoelectric resistivity tomography}

All three geoelectric resistivity profiles generally show a low resistivity on the surface $(<600 \Omega \mathrm{m})$ and higher resistivity $(>3000 \Omega \mathrm{m})$ at a few metres depth, probably due to water- saturated sediments, such as peat or fractured rock, or generally bedrock, respectively (Fig. 10). In addition, in all profiles a pronounced zone of low resistivity $(<1000 \Omega \mathrm{m})$ around $10-30 \mathrm{~m}$ wide is determined that separates areas of higher resistivity $(>2000 \Omega \mathrm{m})$ and that can be traced at depth. The structure is especially well pronounced within profile P1. Here, a c. $10 \mathrm{~m}$-wide 


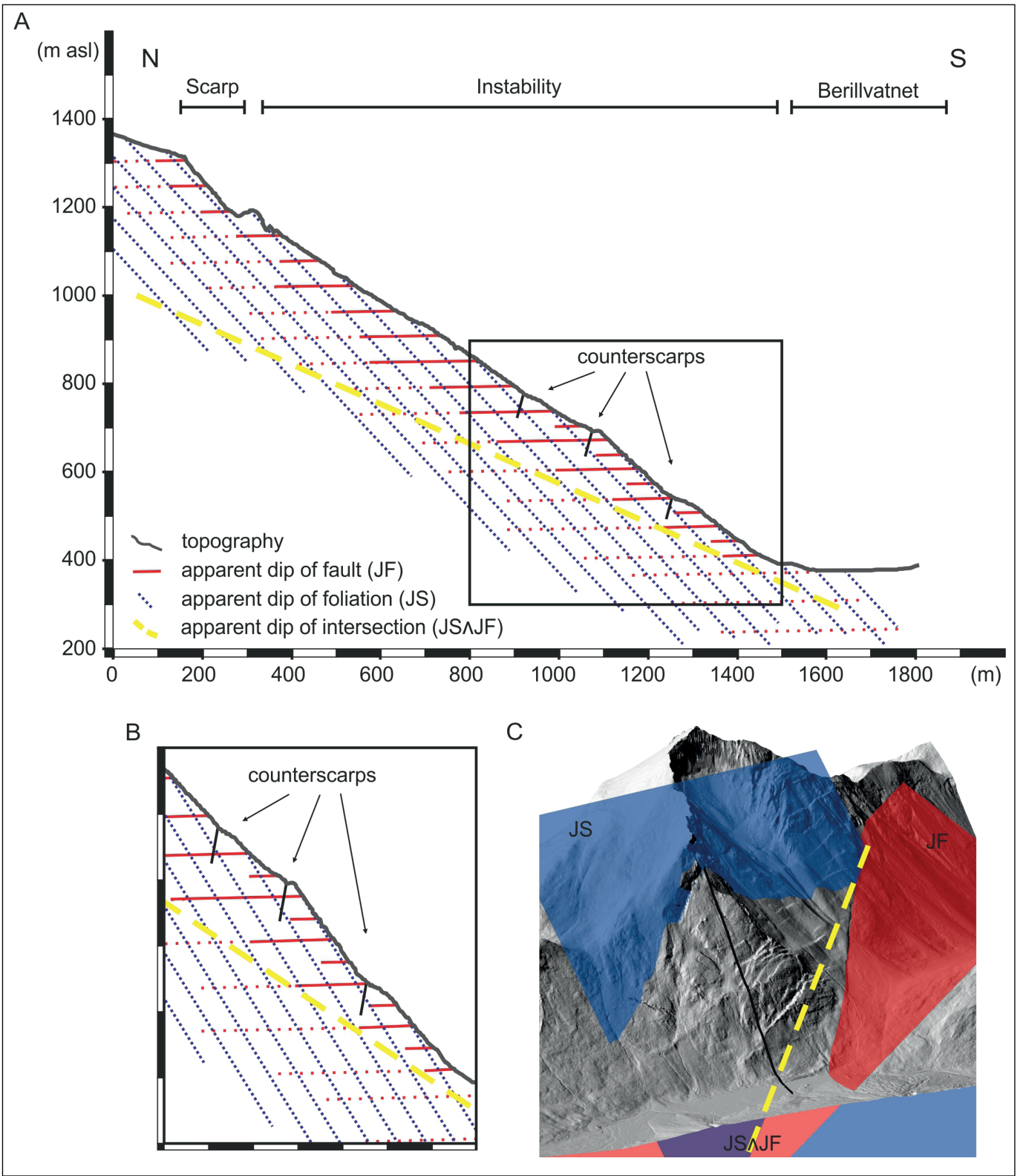

Figure 8. Schematic profile of the rock-slope instability at Middagstinden. The profile trend is parallel to the main movement direction (N-S); for location, refer to Fig. 3. The figures represent the current topography, the apparent dip of the two main limiting discontinuity sets (JS and JF), and their apparent intersection line. (A) Profile along the whole slope, running from the uppermost scarp to the valley bottom. The black rectangle delimits the area of subfigure (B). (B) Closer view of the lower slope section, drawn with a vertical exaggeration of 1.5. (C) Oblique $3 D$ view of the slope, additionally indicating the trace of the profile, running $N-S$ (black line).

low-resistivity zone can be traced at depth that could be linked to the proposed dip direction of the fault. In addition, a second but less pronounced zone of lower resistivity runs parallel to this structure. Within P2 this lowresistivity zone is wider but is narrowing at depth. Furthermore, P3 exhibits a widening of the low-resistivity zone at depth. These differences in the geoelectric resis- tivity profiles will be further explored in section 5.2.2.

The two trenches that run parallel to the geoelectric profiles and cross the position of the fault in this profile were dug down to reach glacial deposits or the bedrock. In both trenches, no deformation structures were detected within the soft sediments (Fig. 11). 
Table 2. Summarised results of the periodic dGNSS displacement measurements at Middagstinden for the years 2008-2015. Error margins (mm/yr) are derived by regression analysis. The associated regression plots are shown in Fig. 9. For locations of the survey points, refer to Fig. 3.

\begin{tabular}{|c|c|c|c|c|c|c|c|c|c|c|c|c|}
\hline \multirow{2}{*}{$\begin{array}{c}\text { dGNSS } \\
\text { point }\end{array}$} & \multicolumn{3}{|c|}{ Coordinates UTM32N $(\mathrm{m})$} & \multirow{2}{*}{$\begin{array}{l}\text { Measurement } \\
\text { period }\end{array}$} & \multicolumn{3}{|c|}{ Displacement rate (mm/year) } & \multicolumn{3}{|c|}{ Error (mm/year) } & \multicolumn{2}{|c|}{$\begin{array}{c}\text { Displacement } \\
\text { direction }\left({ }^{\circ}\right)\end{array}$} \\
\hline & Easting & Northing & Altitude & & Horizontal & Vertical & $3 D$ & Horizontal & Vertical & $3 D$ & Trend & Plunge \\
\hline$\overline{B E R-1}$ & 419485.9 & 6925033.2 & 844.8 & $2008-2015$ & 6.0 & -5.5 & 8.1 & 0.3 & 0.6 & 0.5 & 182 & 42 \\
\hline BER-2 & 419646.6 & 6924887.1 & 712.2 & $2008-2015$ & 4.0 & -2.7 & 4.8 & 0.3 & 0.7 & 0.5 & 189 & 32 \\
\hline BER-3 & 419173.2 & 6924857.1 & 740.2 & $2008-2015$ & 6.3 & -4.9 & 8.0 & 0.3 & 0.7 & 0.5 & 186 & 37 \\
\hline BER-4 & 418886.6 & 6924775.1 & 671.7 & 2009-2015 & 13.2 & -17.4 & 21.9 & 0.2 & 0.5 & 0.4 & 178 & 53 \\
\hline
\end{tabular}
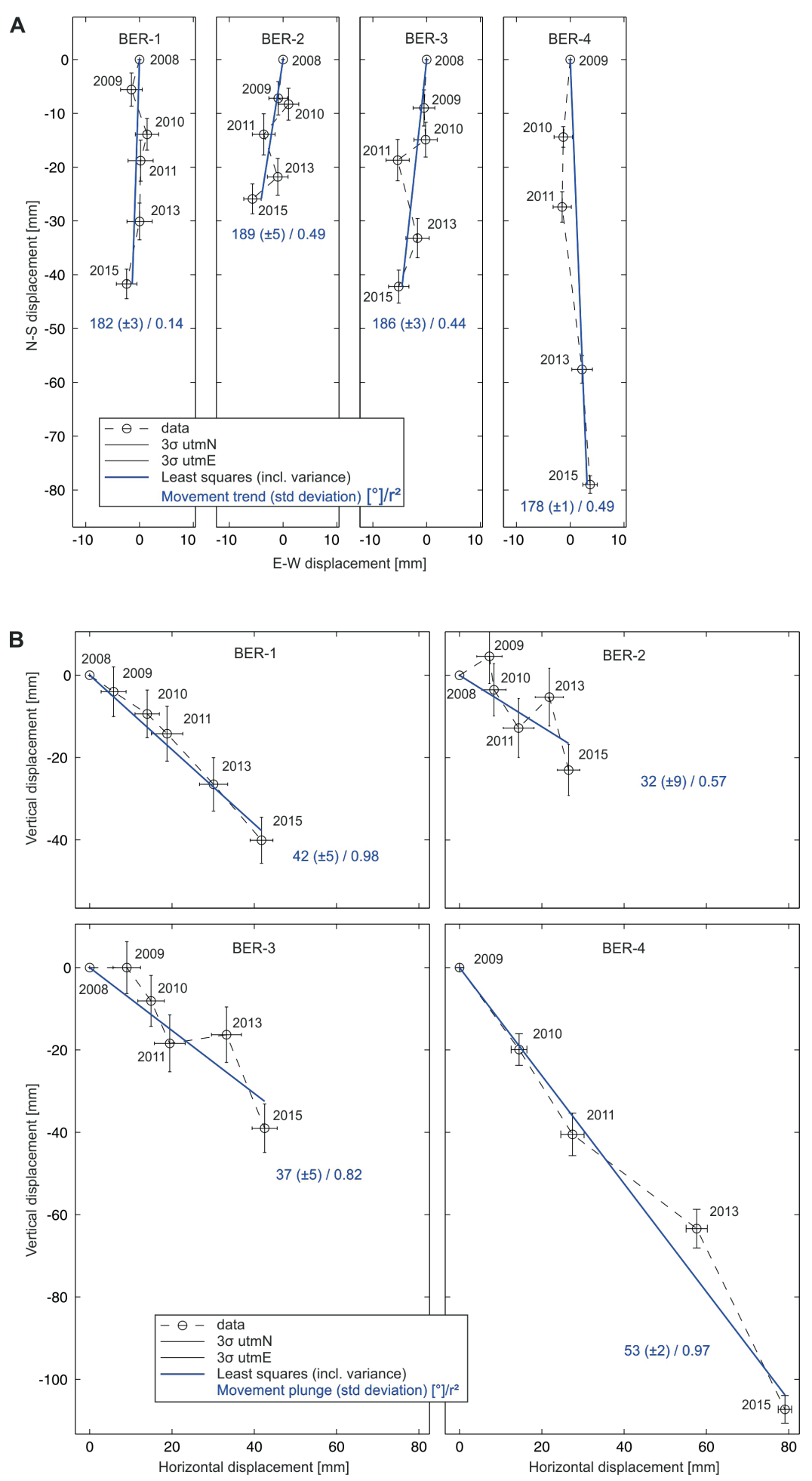

Figure 9. Regression plots of the observed dGNSS displacements on Middagstinden. (A) trend and (B) plunge of the 3D movement vectors of the different rover points (BER-1, BER-2, BER-3 and BER-4, for their locations, refer to Fig. 3). The measurements are summarised in Table 2. 

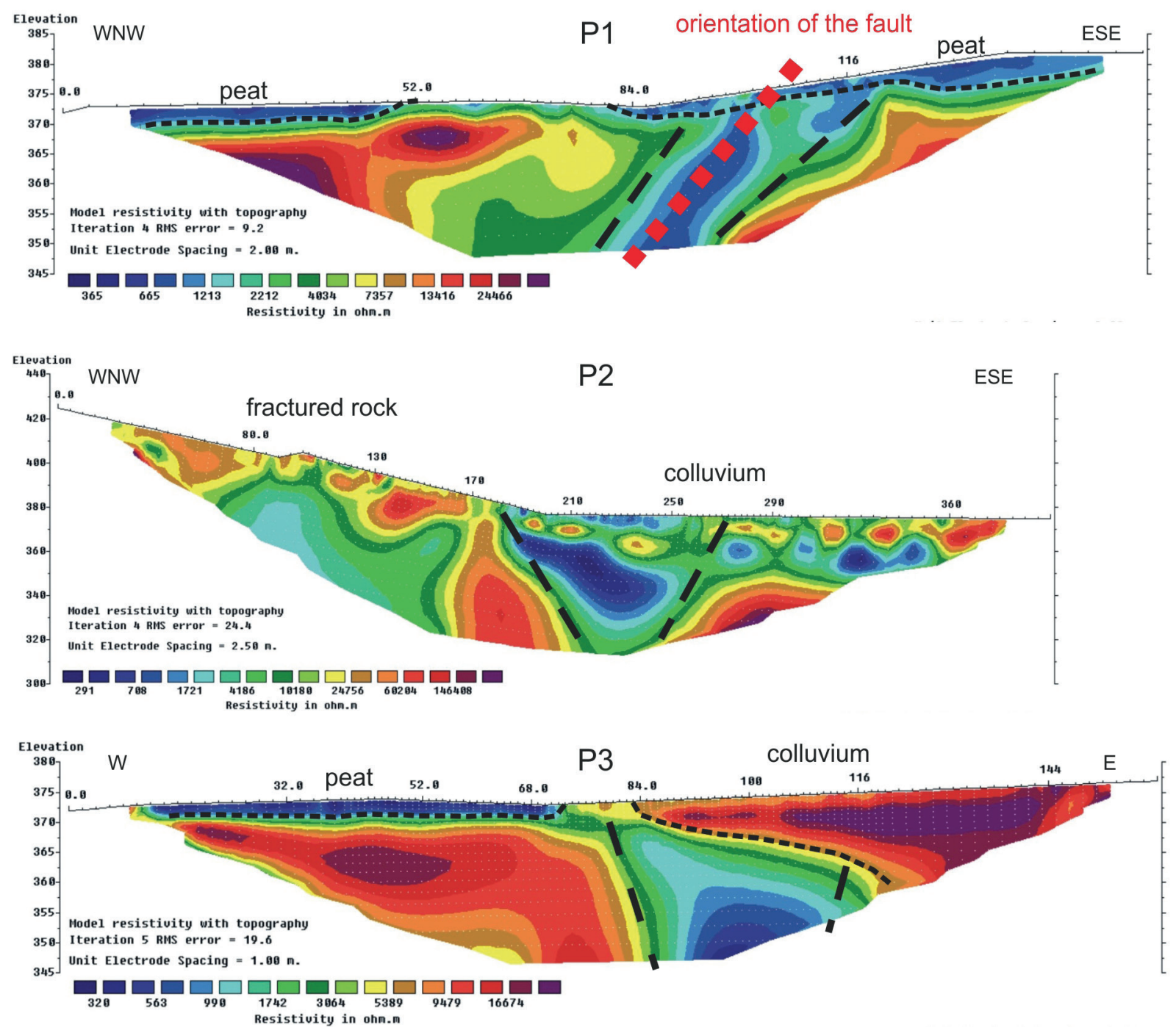

Figure 10. Results of the geoelectric resistivity tomography along the three profiles P1, P2 and P3 at Middagstinden (standard inversion, vertical/ horizontal filter $=1$ ). The profile trends are $120^{\circ}, 95^{\circ}$ and $105^{\circ}$, respectively; for locations, refer to Fig. 3. Relatively low resistivity (blue colours) indicates peat sediments near the lake and/or zones of fractured bedrock along the fault. Note that there are different colour scales on these three profiles.

\section{Discussion}

\section{Characteristics of the rock-slope instability}

Kinematic model

The detailed structural analyses and kinematic feasibility tests led to improved interpretation of the kinematics of the rock-slope instability that differs from the initial model presented by Krieger et al. (2013). Field investigations and structural measurements reveal that the main sliding surface is represented by JS $\left(\sim 158^{\circ} / 49^{\circ}\right)$ (Figs. 3 \& 4B, C). Simple kinematic feasibility tests suggest wedge failure along the intersection line formed by JS and JF $\left(\sim 218^{\circ} / 29^{\circ}\right)$ as the possible failure mechanism (Fig. 7). Planar sliding along JS is possible locally, where the slope angle is $>50^{\circ}$. Because of the variability of the discontinuities, other deformation styles could also have developed along the slope in various sectors. Slight changes in slope aspect do not have any significant influence on the kinematic feasibility tests. However, those feasibility tests can only provide indications (Wyllie \& Mah, 2004), because the tests are generally applicable for simple geometrical settings, such as roadcuts or mines, and for small instabilities, but are often not sufficient to explain complex slope deformations.

For the Middagstinden DSGSD, this is illustrated by the proposed wedge failure mechanism along JSกJF: this is not a viable mechanism for the entire rock-slope instability because the intersection between the planes passing through the back-scarp (parallel to JS) and the Berill Fault (parallel to JF) is not exposed on the slope (Fig. 8C). Therefore, other more complex deformation mechanisms are necessary to explain the observed deformation and the geomorphological characteristics 

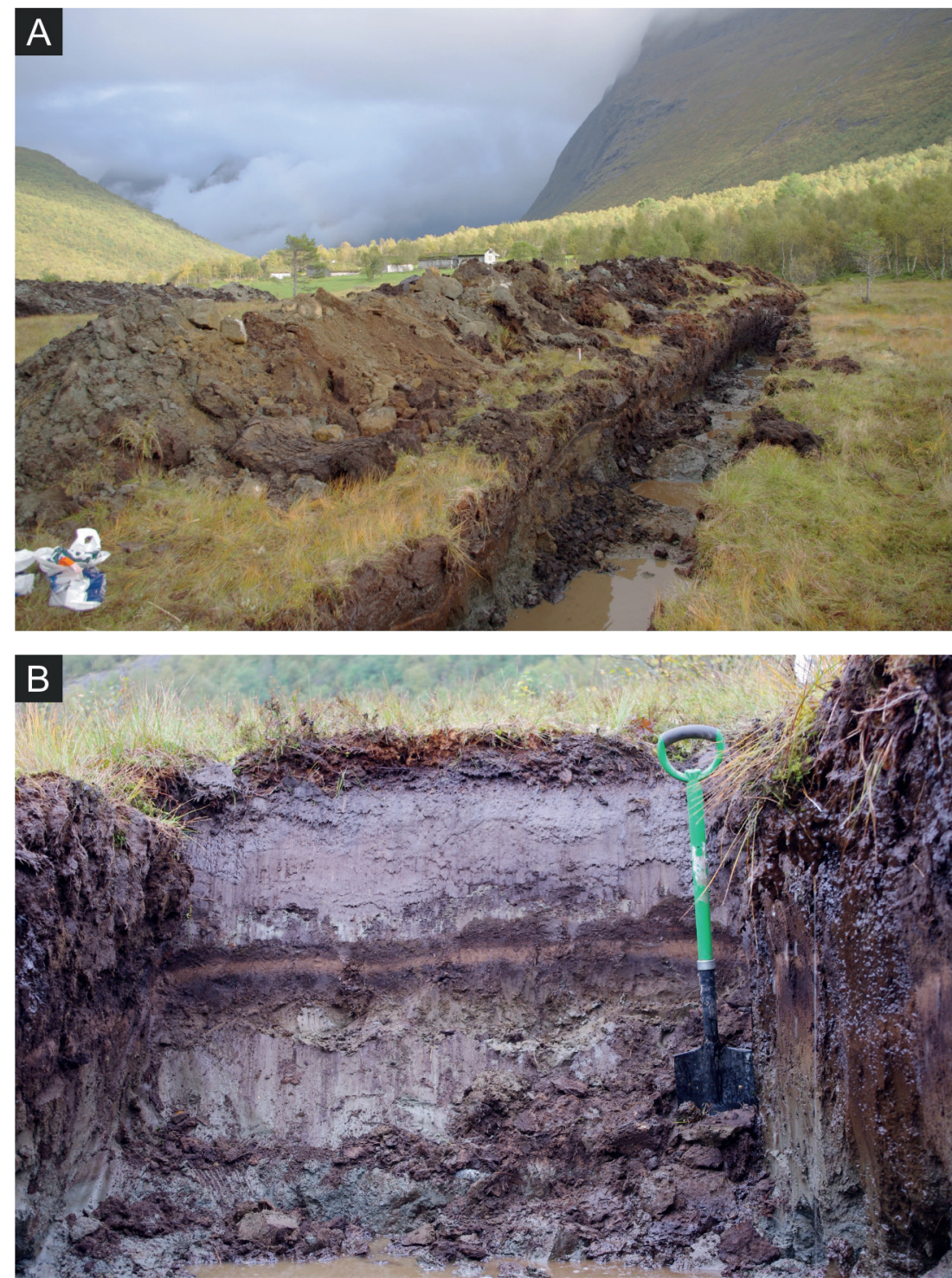

Figure 11. Exemplary photographs of one of the trenches on the valley bottom below Middagstinden running parallel to the geoelectric profile P3. (A) Overview of the c. $20 \mathrm{~m}$-long, $1.5 \mathrm{~m}$-wide and $1.3 \mathrm{~m}$-deep trench in soft sediments. (B) Closer view of the layered soft sediments. The observed sediments do not show any distinct deformation structures. For location, refer to Fig. 3.

of the Middagstinden DSGSD. The kinematics and slope deformation are assumed to be controlled by three main interacting processes that are variable in type and degree.

(1) Planar sliding of rather coherent slide blocks along JS towards SSE controls the uppermost part of the slope (areas 6 and 8). This movement is needed to accommodate the $\sim 80 \mathrm{~m}$ displacement of the rear sliding block. It is also supported by the observed groove marks $\left(\sim 138^{\circ} / 42^{\circ}\right)$ on the exposed sliding plane. Therefore, this movement is $45^{\circ}$ oblique to the general movement that is directed towards the south $\left(\sim 183^{\circ}\right)$ as indicated by the dGNSS measurements (Figs. 3 \& 9; Table 2). However, groove marks could also be formed by small-scale slide activity and should thus be interpreted with caution.

(2) Large wedge failure along JS $\cap J F$ controls the middle part of the slope (mainly areas 4 and middle parts of 6 and 7). Movement along this intersection line is supported by the dGNSS measurements as rover points BER-1 and BER-3 show significant 3D displacements down towards the south (Figs. $3 \&$ 9; Table 2). Furthermore, the variability of structural data (Fig. 5) indicates that the wedge intersection JS $\cap J F$ is steeper in the upper part thus supporting downward sliding, and is less steep in the lower part. This agrees with the intersection of $201^{\circ} / 21^{\circ}$ presented in Krieger et al. (2013) that was measured in the field at a small-scale example located in the lower eastern part (area 7b; Figs. 3 \& 6).

(3) Incremental internal deformation controls the lower part of the slope (areas 7, 9 and 10). As the intersection

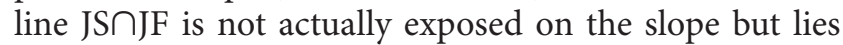
below the valley bottom, the associated sliding is blocked (Fig. 8). This causes deep-seated, internal deformation of 
the rock mass that is not concentrated on a distinct failure surface, but is taken up by multiple structures. This agrees with the S-directed slower displacement rates and shallower plunge angle of rover point BER-2 compared to the other rover points, and with the slope bulging in the lower section of the slope.

The component of large wedge failure (main process 2) could, however, be overestimated. Therefore, an alternative model is interpreted as follows. The whole instability could simply be a two-stage process with planar sliding in the back in areas 6 and 8 (see main process 1 ) followed by internal deformation of the rock mass that hinders the sliding, thus creating counterscarps and bulging of the toe in areas 7 and 10. This model accounts for the displacement of the rear sliding block and could also explain the decrease in plunge angle observed in the dGNSS measurements. In this case, JF is therefore mainly used to delimit small blocks, as also do J1, J2 and J3, which allows incremental internal deformation of the instability. The Berill Fault might still be the lower boundary of the instability by forming a clear weakness zone as indicated by the geoelectric profiles (Fig. 10).

\section{Morphological features and deformation mechanisms} The slope morphology of the rock-slope instability shows typical geomorphological features such as counterscarps, grabens, tension cracks and an irregular slope profile including slope bulging. These features together with the size of the instability, the complex kinematics and the relatively slow deformation rate account for the definition of a DSGSD following the classification of Dramis \& Sorriso-Valvo (1994) and Agliardi et al. (2001, 2012). For this classification, the surface deformation features provide the most important diagnostic characteristics. Furthermore, these features can be linked to the complex deformation mechanisms.

The areas 5 to 10 are interpreted to be subareas within the main rock-slope instability (Fig 3). Area 6 is composed of several coherent slide blocks that are delimited by J1 at the front and by J2 at its lateral limits. Block movement is generally by sliding along JS towards southsoutheast, more or less subparallel to the slope aspect as indicated by groove marks on the sliding plane. This sliding causes compressive stresses in the lower areas, especially in area 7. A distinct geomorphological characteristic of area 7 is the prominent array of subparallel counterscarps and the bulging of the slope. Counterscarps are linear morphological features that are typical for DSGSDs (e.g., Agliardi et al., 2001) but which could also be of tectonic origin (e.g., Hippolyte et al., 2006; Li et al., 2010). For the counterscarps on Middagstinden, a gravitational origin is assumed as they occur in an array parallel to the contours which is a diagnostic feature following Hippolyte et al. (2006) and Li et al. (2010). However, what are the actual processes dealing to the formation of counterscarps?
Gravitational flexural toppling has been suggested by several authors to account for the origin of counterscarps (Hippolyte et al., 2006; Reitner \& Linner, 2009; Li et al., 2010). Li et al. (2010) also suggested that this flexural toppling could contribute to the development of a basal sliding surface or sliding zone in complex largescale slope deformation. However, those examples of large-scale flexural toppling are limited to sedimentary rocks or well-foliated metamorphic rocks with penetrative, subvertical bedding or foliation structures. Based on the interpretation of the kinematic feasibility tests, flexural toppling towards the southeast along the joint set J1 could be suggested as the cause of the counterscarps on Middagstinden. However, the well-developed foliation (JS) that intersects with J1 likely impedes the development of large flexural toppling, although incremental deformation between blocks could be possible. Therefore, we consider that the complex deformation mechanisms, with sliding in the upper slope sections and hindered movement in the lower parts, together with the irregular basal sliding planes, are most likely to have caused the development of the grabens and counterscarps on this slope.

Spreading of fractures due to tensional stresses and brittle failure during block sliding and subsequent erosion of the uphill side can cause counterscarps even in the case of a shallow-dipping sliding plane (Gutiérrez-Santolalla et al., 2005; Li et al., 2010). Moreover, at the transition where the dip of the sliding surface becomes steeper, higher tensional stresses increase brittle failure and rock fragmentation along pre-existing structures, similar to the proposal by Li et al. (2010) for bending moment faults caused by folding at the hinge of an anticline. Preexisting structures, such as here JS and J1, will favour those processes. A steeper sliding surface could further cause acceleration of the sliding block leading to differential movements between the main blocks and different amounts of deformation throughout the rock slope. Sliding surfaces with a succession of flat and ramp areas are proposed for listric-style complex fields that are typical features of large-scale slope deformations in Norway (Braathen et al., 2004). With the varying and partly folded foliation (JS) forming the main sliding surface (Fig. 5) this mechanism is feasible for this site. Moreover, high internal stresses caused by obstructed slope deformation in the lower part of the slope and pushing blocks from behind (area 6) could encourage the formation of counterscarps by stress release due to a kind of 'normal faulting' (Li et al., 2010) along J1.

Within the subarea $7 \mathrm{~b}$ these features are also more distinct, deeper and longer than in 7a (Figs. $3 \& 4 \mathrm{D}, \mathrm{F}$ ). They seem to be slightly stretched and tilted, which can be explained by larger displacements and tensional stress. This would be likely in the case of hindered sliding. The associated southward movement with a smaller downward component further causes the slope bulging in the lower slope section (Fig. 8) due to sliding or toppling out. 
Incremental internal deformation taken up by multiple structures in the subsurface, variably due to JF, J1, J2 and J3, is assumed, which further explains why no distinct failure surface is exposed on the slope.

Within area 7 , the $3 \mathrm{D}$ movement vectors of BER-1 and BER-2 indicate an average S-directed block movement with different rates and plunge angles (Fig. 3; Table 2). The limited horizontal movement agrees with the hindered sliding and toppling out of the lower slope. The survey points are installed on top of rock faces of the counterscarps. The counterscarps indicate fracture along J1 and sliding and toppling towards southeast. However, the combination of this toppling with the SSW-directed wedge sliding along the intersection JS $\cap J F$ could explain the recorded S-directed movement.

The coherent block in the upper western part (area 8) is separated from area 6 by J2 (Fig. 3). BER-3 shows movement rather towards the south (Table 2) but the slightly rotational component of the block indicated by the open cleft might mask the original movement direction. The surrounding large blockfields are results of fractured and collapsed slide blocks indicating a large amount of deformation and fragmentation.

As area 9 is mainly composed of large blockfields, no dGNSS rover point could be installed due to a lack of either coherent blocks or unfractured outcrops. Although a few outcrops exist, these are highly fractured with widely opened discontinuities. The large blockfields are interpreted to be deposits of fractured and collapsed slide blocks. High compressive stresses induced by sliding of the coherent slide blocks (areas 8 and 6) pushing on this part of the slope would also explain the highest amount of deformation and fragmentation along the slope found within this area.

Areas 1 to 4 lie outside of the main rock-slope instability (Fig. 2). Area 4 is covered by surficial glacial and colluvial deposits. and because of the lack of bedrock outcrops it was neither possible to collect structural data nor to install dGNSS rover points. However, this part of the slope could follow a deformation mechanism similar to area 7 of the main instability, as it also shows counterscarps that strike subparallel to those in area 7. As they are much smaller and less deep (up to $3 \mathrm{~m}$ deep and several metres wide in area 4 and up to $20 \mathrm{~m}$ deep and tens of metres wide in area 7), the amount of tensional stress and deformation is assumed to be much less. Here, a large displacement towards south or southwest is either hindered by the slope orientation or stopped by the large unstable rock masses. This is in accordance with Li et al. (2010) who proposed a strong influence of the mountain morphology on stress orientations and kinematics of gravitational deformations. Nevertheless, new satellite-based DInSAR (Differential Interferometry Synthetic Aperture Radar) data using RADASAT-2 images indicate deformation of the whole slope with a similar rate of several mm/yr (J. Dehls, NGU, pers. comm.
2015). This indicates that stresses are taken up either in the subsurface or within the lower part of the slope. Therefore, the distinct geomorphological lineament that has formed along the lower margin of area 4 is considered to be associated with the complex deformation mechanisms and its origin will be explored in the following sections.

\section{Long-term displacements}

The observed displacements are based on periodic dGNSS measurements conducted at single rover points along the surface that also could move independently. Uncertainties due to the influence of superficial movements were strongly reduced or even eliminated by careful choice of the point locations prior to the installation. Therefore, those measurements can provide good indications of the type and amount of slope deformation. To overcome the issues and uncertainties due to point measurements, other area-based monitoring techniques, such as multitemporal terrestrial laser scanning surveys or DInSAR data, can be applied in the future to study the displacements over wider areas or even the whole slope. Oppikofer et al. (2009) have shown, for example, that overall slope displacements and internal slide block rotations can improve our understanding of the complex rock-slope deformation.

Furthermore, the study of long-term displacements will help to understand the failure mechanisms and slope deformation in geological time. The main sliding plane (area 5) is represented by JS (Figs. $3 \& 4$ ) and the exposed mean 3D displacement is around $80 \mathrm{~m}$. By assuming continuous activity since the end of Younger Dryas (YD, approx. $11500 \mathrm{yr}$ ), this displacement indicates an average Holocene movement rate of $6.8 \mathrm{~mm} / \mathrm{yr}$, which is within the range of the measured dGNSS displacements. This assumption is plausible as Middagstinden was out of the ice at around $14000 \mathrm{yr}$ ago (Hughes et al., 2015), which also fits our dating of rock-avalanche deposits in the lower valley (Schleier et al., submitted). However, those average velocities provide only rough indications. More detailed investigations, such as surface-exposure dating of the sliding surface using, for instance, the terrestrial cosmogenic nuclide ${ }^{10} \mathrm{Be}$ (Hermanns et al., 2012b), would be necessary in order to increase our understanding of long-term displacement rates. The displacement rates measured for the western instability (BER-4: $21.9 \mathrm{~mm} /$ yr) are much higher than in the main instability. Assuming a constant velocity over time would give an onset of movements at this instability approximately 230 to 460 years ago (for an opening of the back-scarp by 5-10 m).

\section{Origin of the fault set and the geomorphological lineament}

\section{The fault set - a post-Caledonian structure}

The fault set (JF) is found over the whole rock-slope instability showing a mean orientation of $\sim 271^{\circ} / 43^{\circ}$ with just slight variability (Table 1). The JF strikes subparal- 
lel to the major SSW-NNE-trending tectonic faults in western Norway described by Olsen et al. (2007) to be related to the MTFC (Fig. 1). Significant quartz-feldspar remineralisation and the distinct quartz-feldspar lineation indicate that tectonic fault activity occurred at great depth prior to exhumation. The frequent break-offs indicate a down-dip displacement of the hanging-wall block and therefore a normal-fault movement (Fig. 6A). The mean orientation of the mineral lineation with a trend/ plunge of $\sim 245^{\circ} / 31^{\circ}$, and consequently indicating the direction of fault movement, is subparallel to the direction of the post-Caledonian collapse with SW extensional shearing along the MTFC (Redfield et al., 2005a; Osmundsen et al., 2006). Fault activity at great depth is in accordance with Redfield et al. (2005b) who proposed normal activity of the MTFC at depth and a crustal uplift in the order of $2-3 \mathrm{~km}$. However, the lineation does not occur continuously on all surfaces of the JFand the planes show varying orientations throughout the slope and are partly undulating (Fig. 5). Therefore, we interpretthe JF to have followed a pre-existing discontinuity, which was a preconditioned zone of weakness in the course of faulting during the post-Caledonian collapse and that the extensional activity took place in this tectonic phase.

\section{The geomorphological lineament -} not a neotectonic reverse fault

The distinct geomorphological lineament (Figs. 3 \& 4) was previously interpreted as the surface expression of a neotectonic reverse fault, named the Berill Fault (Anda et al., 2002). Field observations in this study and the geological model of the Middagstinden DSGSD have led to a reinterpretation of the origin of this lineament. Tectonic movement along the JF is normal instead of reverse (Fig. $6 \mathrm{~A})$. The extent of the fault trace is suggested to be more regional since it is also detectable at the backside, that is, on the NE-dipping slope of the mountain (Fig. 2) (Anda et al., 2002).

The pronounced low electric resistivity zones $(<1000$ $\Omega \mathrm{m}$ ) detected in the geoelectric resistivity profiles along the valley (Fig. 10) are interpreted to represent the prolongation of the fault. Following Rønning et al. (2014), in this area a resistivity of $<3000 \Omega \mathrm{m}$ can be interpreted as fractured rock, $<500 \Omega \mathrm{m}$ as fractured clay-altered rock, and values $>3000 \Omega \mathrm{m}$ as massive bedrock. With uncertainties, especially for the pronounced zone in P1, a dip direction similar to that of the observed fault can be inferred. However, fractured/altered rock could show a confusing pattern when talking about dip in those profiles. This can be partly explained by incomplete inversion and/or geology. For instance, different materials, such as fractured and deformed rock or colluvium or rock-avalanche deposits, and different water contents of these materials can mask the boundaries. Especially the opening of the fault zone towards depth along profile P3 may be an artificial effect, according to modelling by Reiser et al. (2009), or the fault might be masked by surficial deposits.
With the new knowledge of the orientation of JF, it is now even possible to trace the lineament farther on the opposite valley slope (Fig. 2). However, the trenches opened along the resistivity profiles exhibit no soft-sediment deformation features within the glacial deposits that could indicate seismic activity (Figs. $3 \& 11$ ).

Thus, although this fault set was active during the postCaledonian collapse, no neotectonic reactivation has occurred along the slope. Therefore, the so-called Berill Fault can no longer be considered as the first evidence of neotectonic activity in southern Norway as proposed by Anda et al. (2002). This also agrees with the regional investigations by Olesen et al. (2013) who meanwhile had removed this reverse fault from their list of "almost certainly neotectonics" and inferred instead a gravitational origin. Since Anda et al. (2002) and Blikra et al. (2002) suggested neotectonic seismicity and associated earthquakes as the main cause of the cluster of large rockslope failures in this region based on the previous interpretation, now the triggering factors need to be reinvestigated.

\section{The geomorphological lineament -}

an 'apparent reverse fault'

The new findings on the origin of the JF fault set together with detailed investigations of the neighbouring DSGSD enable a reinterpretation of the origin of the geomorphological lineament. In general, linear features along a slope, such as the observed lineament, could be related either to tectonic or to gravitational processes whereby length and linearity could indicate a tectonic origin (Thompson et al., 1997). With reference to this work, the observed lineament is considered to be rather of gravitational origin, because it is relatively short and no similar offset has been found in other stable parts of the mountain (Fig. 2). A gravitational model is further supported by the fact that no deformation structures are found in lower parts of the slope or down on the valley floor, neither in topography (Fig. 4F) nor in the trenches (Fig. 11), which is similar to the study of Hippolyte et al. (2006). The counterscarps in area 4 on the slope above this lineament (Figs. 3 \& 4B) also suggest a gravitational origin because of the typical characteristic features proposed by Hippolyte et al. (2006) and Li et al. (2010), i.e., swarms of relatively short, mainly uphill-facing scarps that cut scree deposits and occur largely parallel to the ridge crest and the contours.

Moreover, the proposed kinematic model of the DSGSD can explain the origin of the distinct geomorphological lineament. The large wedge failure (trend $218^{\circ}$ ) causes movement out of the slope in a direction $43^{\circ}$ oblique to the mean slope aspect $\left(175^{\circ}\right)$ (Figs. $7 \& 8$ ). This movement, in combination with the sliding component along JS and the proposed low friction along JF (e.g., slickensided, planar and subhorizontal apparent dip in the direction of movement), produces a surficial positive offset (Figs. 6B \& 8). This offset appears similar to an apparent thrusting 
along the JF in an eastward direction. This would be similar to a flexural slip on bedding planes due to gravitational load in a syncline (Li et al., 2010). However, in the present case the offset is not related to folding but to gravitational reactivation of the pre-existing fault that exhibits a shallow apparent dip in the movement direction. Although no E-directed displacement is observed on the entire slope in the InSAR data, the observed S-directed movement that is oblique to the wedge intersection (Fig. 7) can also result in such a positive relief step along the fault. Thereby, the rock mass is not pushed upwards to the east but towards the south, thus causing the offset that is therefore not reverse but oblique. This offset is largest along the southeastern boundary of the instability forming the geomorphological lineament that disappears towards the valley bottom (Figs. $2 \& 4$ ). Its disappearance is related to increased possibilities for stress release, for instance due to changing slope aspect and in form of greater amounts of deformation in the lower slope section. Therefore, the observed geomorphological lineament is interpreted to be the surface expression of an 'apparent reverse fault' formed by gravitational reactivation of a pre-existing post-Caledonian fault set and hence of pseudotectonic origin.

\section{Conclusions}

The rock-slope instability of Middagstinden shows diagnostic characteristics of a DSGSD and exhibits features signifying exploitation of pre-existing tectonic structures. Based on the detailed investigations, the following main conclusions can be drawn.

(I) The DSGSD shows evidence of complex deformation mechanisms that are controlled by slope topography and five discontinuity sets including the metamorphic foliation, a fault-parallel set and two major and one minor joint sets. The fault set is proposed to be a pre-existing discontinuity set (e.g., joint set) that has been exploited as a weakness zone during collapse of the Caledonian orogeny. Quartz-feldspar remineralisation with lineation and break-offs indicate a normal fault process at great depth. The complex kinematics of the DSGSD consist of up to three main deformation mechanisms changing along the slope in type and degree: (1) planar sliding along the foliation in the uppermost part, (2) wedge sliding along the foliation and the fault set in the middle part, and (3) incremental internal deformation on multiple structures due to hindered planar and wedge sliding in the lower part. Alternatively, a two-stage process consisting of only mechanism 1 and 3 could also be possible. The deformation mechanisms on the slope can be linked to distinct geomorphological features which are distributed over various areas of the slope, such as large coherent slide blocks, up to $20 \mathrm{~m}$ deep counterscarps, small-scale superficial mass movements, and morphological slope bulging. The current mean displace- ments are about $8 \mathrm{~mm} / \mathrm{yr}$ in the upper part of the main instability and about $5 \mathrm{~mm} / \mathrm{yr}$ in the lower part. In consideration of average displacement rates since Younger Dryas, they indicate a rather constant displacement rate. However, our understanding of long-term displacements requires further investigations such as surface-exposure dating of the sliding plane.

(II) The prominent geomorphological lineament at Middagstinden, previously described as the Berill Fault, requires reinterpretation. It is not the surface expression of a neotectonic reverse fault, but an example of pseudotectonics due to gravitational reactivation of the postCaledonian normal fault set as a weakness zone by the DSGSD. The complex deformation mechanisms with a displacement direction oblique to the fault set, together with varying slope orientations, have resulted in a positive offset along the fault set. The surface expression is a convex step in the topography running oblique to the slope along the southeastern boundary of the DSGSD that can be described as an 'apparent reverse fault'. This reinterpretation of the Berill Fault further requires new discussion of the triggering mechanisms for the cluster of large rock-slope failures in this region that are neotectonic.

Acknowledgements. This research received financial support from the Norwegian Water Resources and Energy Directorate within the framework of the project 'Rock avalanche mapping in Møre og Romsdal County.' Thanks also to J.J. Clague and A. Saintot who participated during the trench excavation as part of a collaborative activity financed through the International Centre for Geohazards (ICG), financed by the Norwegian Research Council (NFR). Thanks to E. Dalsegg for performing the electrical resistivity measurements and to T. Deans for reading the original version of the manuscript. This paper is based on a subchapter of the doctoral thesis of M. Schleier (2016) on rock-slope failures in Innerdalen and Innfjorddalen, western Norway.

\section{References}

ABEM 1999: ABEM Terrameter SAS 4000/SAS 1000. Instruction Manual. ABEM Printed Matter 93101, 95 pp.

Agliardi, F., Crosta, G. \& Zanchi, A. 2001: Structural constraints on deep-seated slope deformation kinematics. Engineering Geology 59, 83-102. doi: 10.1016/s0013-7952(00)00066-1.

Agliardi, F., Crosta, G.B. \& Frattini, P. 2012: Slow rock-slope deformation. In Clague, J.J. \& Stead, D. (eds.): Landslides: Types, Mechanisms and Modeling, Cambridge University Press, New York, pp. 207-221.

Ambrosi, C. \& Crosta, G.B. 2006: Large sackung along major tectonic features in the Central Italian Alps. Engineering Geology 83, 183200. doi: 10.1016/j.enggeo.2005.06.031.

Anda, E., Blikra, L.H. \& Braathen, A. 2002: The Berill Fault - first evidence of neotectonic faulting in southern Norway. Norwegian Journal of Geology 82, 175-182.

Blikra, L.H. \& Christiansen, H.H. 2014: A field-based model of permafrost-controlled rockslide deformation in northern Norway. Geomorphology 208, 34-49. doi: 10.1016/j.geomorph.2013.11.014.

Blikra, L.H., Braathen, A., Anda, E., Stalsberg, K. \& Longva, O. 2002: Rock avalanches, gravitational bedrock fractures and neotectonic 
faults onshore northern West Norway: Examples, regional distribution and triggering mechanisms. Norges geologiske undersøkelse Report 2002.016, 48 pp.

Böhme, M., Hermanns, R.L., Fischer, L., Oppikofer, T., Bunkholt, H., Derron, M.-H., Carrea, D., Jaboyedoff, M. \& Eiken, T. 2012: Detailed assessment of the deep-seated gravitational deformation at Stampa above Flåm, Norway. In Eberhardt, E., Froese, C., Turner, K. \& Leroueil, S. (eds.): Landslides and Engineered Slopes: Protecting Society through Improved Understanding, Taylor \& Francis Group, London, pp. 647-652.

Böhme, M., Hermanns, R.L., Oppikofer, T., Fischer, L., Bunkholt, H.S.S., Eiken, T., Pedrazzini, A., Derron, M.-H., Jaboyedoff, M., Blikra, L.H. \& Nilsen, B. 2013: Analyzing complex rock slope deformation at Stampa, western Norway, by integrating geomorphology, kinematics and numerical modeling. Engineering Geology 154, 116-130. doi: 10.1016/j.enggeo.2012.11.016.

Booth, A.M., Lamb, M.P., Avouac, J.-P. \& Delacourt, C. 2013: Landslide velocity, thickness, and rheology from remote sensing: La Clapière landslide, France. Geophysical Research Letters 40, 4299-4304. doi: 10.1002/grl.50828.

Booth, A., Dehls, J., Eiken, T., Fischer, L., Hermanns, R. \& Oppikofer, T. 2014: Integrating diverse geologic and geodetic observations to determine failure mechanisms and deformation rates across a large bedrock landslide complex: the Osmundneset landslide, Sogn og Fjordane, Norway. Landslides, 1-12. doi: 10.1007/s10346-0140504-y.

Braathen, A., Blikra, L.H., Berg, S.S. \& Karlsen, F. 2004: Rock-slope failures in Norway; type, geometry, deformation mechanisms and stability. Norwegian Journal of Geology 84, 67-88.

Brideau, M.-A., Yan, M. \& Stead, D. 2009:. The role of tectonic damage and brittle rock fracture in the development of large rock slope failures. Geomorphology 103, 30-49. doi:10.1016/j.geomorph.2008.04.010.

Cossart, E., Braucher, R., Fort, M., Bourlès, D.L. \& Carcaillet, J. 2008: Slope instability in relation to glacial debuttressing in alpine areas (Upper Durance catchment, southeastern France): Evidence from field data and 10Be cosmic ray exposure ages. Geomorphology 95, 3-26. doi:10.1016/j.geomorph.2006.12.022.

Dahlin, T. 1993: On the Automation of 2D Resistivity Surveying for Engineering and Environmental Applications. PhD thesis, Lund University, $187 \mathrm{pp}$.

Dehls, J.F., Olesen, O., Bungum, H., Hicks, E.C., Lindholm, C.D. \& Riis, F. 2000: Neotectonic map: Norway and adjacent areas. Geological Survey of Norway, Trondheim.

Dramis, F. \& Sorriso-Valvo, M. 1994: Deep-seated gravitational slope deformations, related landslides and tectonics. Engineering Geology 38, 231-243.

Eberhardt, E., Stead, D. \& Coggan, J.S. 2004: Numerical analysis of initiation and progressive failure in natural rock slopes-the 1991 Randa rockslide. International Journal of Rock Mechanics and Mining Sciences 41, 69-87. doi:10.1016/S1365-1609(03)00076-5.

Evans, S.G. \& Clague, J.J. 1994: Recent climatic change and catastrophic geomorphic processes in mountain environments. Geomorphology 10, 107-128.

Fischer, L., Kääb, A., Huggel, C. \& Noetzli, J. 2006: Geology, glacier retreat and permafrost degradation as controlling factors of slope instabilities in a high-mountain rock wall: the Monte Rosa east face. Natural Hazards and Earth System Sciences 6, 761-772. doi:10.5194/nhess-6-761-2006.

Gabrielsen, R.H., Braathen, A., Dehls, J. \& Roberts, D. 2002: Tectonic lineaments of Norway. Norwegian Journal of Geology 82, 153-174.

Ganerød, G.V., Grøneng, G., Rønning, J.S., Dalsegg, E., Elvebakk, H., Tønnesen, J.F., Kveldsvik, V., Eiken, T., Blikra, L.H. \& Braathen, A. 2008: Geological model of the Åknes rockslide, western Norway. Engineering Geology 102, 1-18. doi:10.1016/j.enggeo.2008.01.018.

Gischig, V., Amann, F., Moore, J.R., Loew, S., Eisenbeiss, H. \& Stempfhuber, W. 2011: Composite rock slope kinematics at the current Randa instability, Switzerland, based on remote sensing and numerical modeling. Engineering Geology 118, 37-53. doi:10.1016/j.enggeo.2010.11.006.

Gutiérrez-Santolalla, F., Acosta, E., Ríos, S., Guerrero, J. \& Lucha, P. 2005: Geomorphology and geochronology of sackung features (uphill-facing scarps) in the Central Spanish Pyrenees. Geomorphology 69, 298-314. doi:10.1016/j.geomorph.2005.01.012.

Hacker, B.R., Andersen, T.B., Johnston, S., Kylander-Clark, A.R.C., Peterman, E.M., Walsh, E.O. \& Young, D. 2010: High-temperature deformation during continental-margin subduction and exhumation: The ultrahigh-pressure Western Gneiss Region of Norway. Tectonophysics 480, 149-171. doi:10.1016/j.tecto.2009.08.012.

Henderson, I.H.C. \& Saintot, A. 2011: Regional spatial variations in rockslide distribution from structural geology ranking: an example from Storfjorden, western Norway. Geological Society, London, Special Publications 351, 79-95. doi:10.1144/sp351.4.

Hermanns, R.L. \& Strecker, M.R. 1999: Structural and lithological controls on large Quaternary rock avalanches (sturzstroms) in arid northwestern Argentina. Geological Society of America Bulletin 111, 934-948. doi:10.1130/0016-7606(1999)111<0934:salcol>2.3.co;2.

Hermanns, R.L., Niedermann, S., Garcia, A.V., Gomez, J.S. \& Strecker, M.R. 2001: Neotectonics and catastrophic failure of mountain fronts in the southern intra-Andean Puna Plateau, Argentina. Geology 29, 619-622. doi:10.1130/0091-7613(2001)029<0619:nacfom> 2.0.co;2.

Hermanns, R.L., Oppikofer, T., Anda, E., Blikra, L.H., Böhme, M., Bunkholt, H., Crosta, G.B., Dahle, H., Devoli, G., Fischer, L., Jaboyedoff, M., Loew, S., Sætre, S. \& Yugsi Molina, F.X. 2012a: Recommended hazard and risk classification system for large unstable rock slopes in Norway.NGU Report 2012.029. Geological Survey of Norway.

Hermanns, R.L., Redfield, T.F., Bunkholt, H.S.S., Fischer, L., Oppikofer, T., Gosse, J. \& Eiken, T. 2012b: Cosmogenic nuclide dating of slow moving rockslides in Norway in order to assess long-term slide velocities. In Eberhardt, E., Froese, C., Turner, K. \& Leroueil, S. (eds.): Landslides and Engineered Slopes: Protecting Society through Improved Understanding. Taylor \& Francis Group, London, pp. 849854.

Hermanns, R.L., Oppikofer, T., Dahle, H., Eiken, T., Ivy-Ochs, S. \& Blikra, L.H. 2013: Understanding long-term slope deformation for stability assessment of rock slopes: the case of the Oppstadhornet rockslide, Norway. Italian Journal of Engineering Geology and Environment, Book Series 6, 255-264. doi:10.4408/IJEGE.2013-06.B-23.

Hippolyte, J.-C., Brocard, G., Tardy, M., Nicoud, G., Bourles, D., Braucher, R., Menard, G. \& Souffache, B. 2006: The recent fault scarps of the Western Alps (France): Tectonic surface ruptures or gravitational sackung scarps? A combined mapping, geomorphic, levelling, and 10Be dating approach. Tectonophysics 418, 255-276. doi:10.1016/j.tecto.2006.02.009.

Hippolyte, J.-C., Bourlès, D., Braucher, R., Carcaillet, J., Léanni, L., Arnold, M. \& Aumaitre, G. 2009: Cosmogenic 10Be dating of a sackung and its faulted rock glaciers, in the Alps of Savoy (France). Geomorphology 108, 312-320. doi:10.1016/j.geomorph.2009.02.024.

Hughes, A.L.C., Gyllencreutz, R., Lohne, Ø.S., Mangerud, J. \& Svendsen, J.I. 2015. The last Eurasian ice sheets - a chronological database and time-slice reconstruction, DATED-1. Boreas 45, 1-45. doi: 10.1111/bor.12142.

Hutchinson, J.N. 1988: General Report: morphological and geotechnical parameters of landslides in relation to geology and hydrogeology. In Bonnard, C. (ed.): Fifth International Symposium on Landslides. A.A. Balkema, Rotterdam, pp. 3-36.

ISRM (International Society of Rock Mechanics) 1981: Suggested methods for the quantitative description of discontinuities in rock masses (Brown, E.T. (ed.)). Pergamon Press, Oxford, pp. 211.

Jomard, H., Lebourg, T. \& Guglielmi, Y. 2014: Morphological analysis of deep-seated gravitational slope deformation (DSGSD) in the western part of the Argentera massif. A morpho-tectonic control? Landslides 11, 107-117. doi:10.1007/s10346-013-0434-0.

Krieger, I., Hermanns, R.L., Schleier, M., Yugsi Molina, F.X., Oppikofer, T., Rønning, J.S., Eiken, T. \& Rohn, J. 2013: The Berill fault and its 
relation to a deep seated gravitational slope deformation (DSGSD). In Genevois, R. \& Prestininzi, A. (eds.): International Conference on Vajont - 1963-2013 - Thoughts and analyses after 50 years since the catastrophic landslide, Padua, Italy, 8-10. October 2013. Italian Journal of Engineering Geology and Environment, Book Series 6, 265-273.

Li, Z., Bruhn, R.L., Pavlis, T.L., Vorkink, M. \& Zeng, Z. 2010: Origin of sackung uphill-facing scarps in the Saint Elias orogen, Alaska: LIDAR data visualization and stress modeling. Geological Society of America Bulletin 122, 1585-1599. doi:10.1130/B30019.1.

Nasuti, A., Pascal, C. \& Ebbing, J. 2012: Onshore-offshore potential field analysis of the Møre-Trøndelag Fault Complex and adjacent structures of Mid Norway. Tectonophysics 518-521, 17-28. doi:10.1016/j.tecto.2011.11.003.

Nordgulen, Ø. \& Andresen, A. 2008: The Precambrian - The oldest rocks are formed; 4600-850 Ma. In Ramberg, I.B., Bryhni, I., Nøttvedt, A. \& Rangnes, K. (eds.): The Making of a Land - Geology of Norway. Norsk Geologisk Forening, Trondheim, pp. 62-119.

Olesen, O., Blikra, L.H., Braathen, A., Dehls, J.F., Olsen, L., Rise, L., Roberts, D., Riis, F., Faleide, J.I. \& Anda, E. 2004: Neotectonic deformation in Norway and its implications: a review. Norwegian Journal of Geology 84, 3-34.

Olesen, O., Bungum, H., Dehls, J., Lindholm, C., Pascal, C. \& Roberts, D. 2013: Neotectonis, seismisity and contemporary stress field in Norway - mechanisms and implications. In Olsen, L., Fredin, O. \& Olesen, O. (eds.): Quaternary Geology of Norway. NGU Special Publication 13, pp. 145-174. Geological Survey of Norway, Trondheim.

Olsen, A.E.V., Gabrielsen, R.H., Braathen, A. \& Redfield, T.F. 2007: Fault systems marginal to the Møre-Trøndelag Fault Complex, Central Norway. Norwegian Journal of Geology 87, 59-73.

Oppikofer, T., Jaboyedoff, M., Blikra, L.H., Derron, M.-H. \& Metzger, R. 2009: Characterization and monitoring of the Aknes rockslide using terrestrial laser scanning. Natural Hazards and Earth System Sciences 9, 1003-1019.

Oppikofer, T., Nordahl, B., Bunkholt, H., Nicolaisen, M., Jarna, A., Iversen, S., Hermanns, R.L., Böhme, M. \& Yugsi Molina, F.X. 2015: Database and online map service on unstable rock slopes in Norway - From data perpetuation to public information. Geomorphology 249, 69-81. doi:10.1016/j.geomorph.2015.08.005.

Osmundsen, P.T.. Eide, E. A, Haabesland, N. E., Roberts, D., Andersen, T. B., Kendrick, M., Bingen, B., Braathen, A. \& Redfield, T. F. 2006: Kinematics of the Høybakken detachment zone and the MøreTrøndelag Fault Complex, central Norway. Journal of the Geological Society, London 163, 303-318.

Osmundsen, P.T., Henderson, I., Lauknes, T.R., Larsen, Y., Redfield, T.F. \& Dehls, J. 2009: Active normal fault control on landscape and rock-slope failure in northern Norway. Geology 37, 135-138. doi:10.1130/g25208a.1.

Penna, I.M., Hermanns, R.L., Niedermann, S. \& Folguera, A. 2011: Multiple slope failures associated with neotectonic activity in the Southern Central Andes ( $\left.37^{\circ}-37^{\circ} 30 \bigotimes \mathrm{S}\right)$, Patagonia, Argentina. Geological Society of America Bulletin 123, 1880-1895. doi:10.1130/ B30399.1.

Redfield, T.F., Braathen, A., Gabrielsen, R.H., Osmundsen, P.T.,Torsvik, T.H. \& Andriessen, P.A.M. 2005a: Late Mesozoic to Early Cenozoic components of vertical separation across the Møre-Trøndelag Fault Complex, Norway. Tectonophysics 395, 233- 249. doi:10.1016/j.tecto.2004.09.012.

Redfield, T.F., Osmundsen, P.T. \& Hendriks, B.W.H. 2005b: The role of fault reactivation and growth in the uplift of western Fennoscandia. Journal of the Geological Society 162, 1013-1030. doi: 10.1144/0016-764904-149.

Reiser, F., Dalsegg, E., Dahlin, T., Ganerød, G. \& Rønning, J.S. 2009: Resistivity modelling of fracture zones and horizontal layers in bedrock. NGU Report 2009.070. Geological Survey of Norway, Trondheim.

Reitner, J.M. \& Linner, M. 2009: Formation and preservation of large scale toppling related to alpine tectonic structures - Eastern Alps. Austrian Journal of Earth Sciences 102, 69-80.

Rocscience (2015): https://www.rocscience.com (access 20. Jan. 2015).

Rønning, J.S., Dalsegg, E., Elvebakk, H., Ganerød, G.V. \& Heincke, B.H. 2009: Characterization of fracture zones in bedrock using 2D resistivity, Proceedings from 5th Seminar on Strait Crossings, Trondheim, pp. 439-444.

Rønning, J., Ganerød, G., Dalsegg, E. \& Reiser, F. 2014: Resistivity mapping as a tool for identification and characterisation of weakness zones in crystalline bedrock: definition and testing of an interpretational model. Bulletin of Engineering Geology and the Environment 73, 1225-1244. doi:10.1007/s10064-013-0555-7.

Saintot, A., Henderson, I.H.C. \& Derron, M.-H. 2011: Inheritance of ductile and brittle structures in the development of large rock slope instabilities: examples from western Norway. Geological Society, London, Special Publications 351, 27-78. doi:10.1144/sp351.3.

Saintot, A., Oppikofer, T., Derron, M.H. \& Henderson, I. 2012: Large gravitational rock slope deformation in Romsdalen Valley (Western Norway). Revista de la Asociación Geológica Argentina 69, 354-371.

Schleier, M., Hermanns, R.L. \& Rohn, J. 2013: Spatial distribution of rockslide deposits and their morphological features suggest timing and palaeo-environmental conditions for rock slope failures in Innerdalen and Innfjorddalen, Møre og Romsdal county, western Norway. In Genevois, R. \& Prestininzi, A. (eds.): International Conference on Vajont - 1963-2013 - Thoughts and analyses after 50 years since the catastrophic landslide, Padua, Italy, 8-10. October 2013. Italian Journal of Engineering Geology and Environment, Book Series 6, pp. 493505 .

Schleier, M., Hermanns, R.L., Gosse, J.C., Oppikofer, T., Rohn, J. \& Tønnesen, J.F., submitted: Subaqueous rock-avalanche deposits exposed by post-glacial isostatic rebound, Innfjorddalen, Western Norway. Geomorphology.

Solberg, I.L., Rønning, J.S., Dalsegg, E., Hansen, L., Rokoengen, K. \& Sandven, R. 2008: Resistivity measurements as a tool for outlining quick clay extents and valley fill stratigraphy: feasability study from Buvika, Central Norway. Canadian Geotechnical Journal 45, 210-225.

Stead, D., Eberhardt, E. \& Coggan, J.S. 2006: Developments in the characterization of complex rock slope deformation and failure using numerical modelling techniques. Engineering Geology 83, 217-235. doi:10.1016/j.enggeo.2005.06.033.

Thompson, S.C., Clague, J.J. \& Evans, S.G. 1997: Holocene Activity of the Mt. Currie Scarp, Coast Mountains, British Columbia, and Implications for its Origin. Environmental and Engineering Geoscience III, 329-348.

Tveten, E., Lutro, O. \& Thorsnes, T. 1998: Geologisk kart over Norge, Berggrunnskart Ålesund, 1:250,000. Geological Survey of Norway, Trondheim.

Welkner, D., Eberhardt, E. \& Hermanns, R.L. 2010: Hazard investigation of the Portillo Rock Avalanche site, central Andes, Chile, using an integrated field mapping and numerical modelling approach. Engineering Geology 114, 278-297. doi:10.1016/j.enggeo.2010.05.007.

Willenberg, H., Loew, S., Eberhardt, E., Evans, K.F., Spillmann, T., Heincke, B., Maurer, H. \& Green, A.G. 2008: Internal structure and deformation of an unstable crystalline rock mass above Randa (Switzerland): Part I - Internal structure from integrated geological and geophysical investigations. Engineering Geology 101, 1-14. doi:10.1016/j.enggeo.2008.01.015.

Wolter, A., Stead, D. \& Clague, J.J. 2014: A morphologic characterisation of the 1963 Vajont Slide, Italy, using long-range terrestrial photogrammetry. Geomorphology 206, 147-164. doi:10.1016/j.geomorph.2013.10.006.

Wyllie, D.C. \& Mah, C.W. 2004: Rock Slope Engineering. Civil and Mining. Spon Press, London.

Zischinsky, U. 1969: Über Sackungen. Rock Mechanics 1, 30-52. doi:10.1007/bf01247356. 